\title{
Lectins: an effective tool for screening of potential cancer biomarkers
}

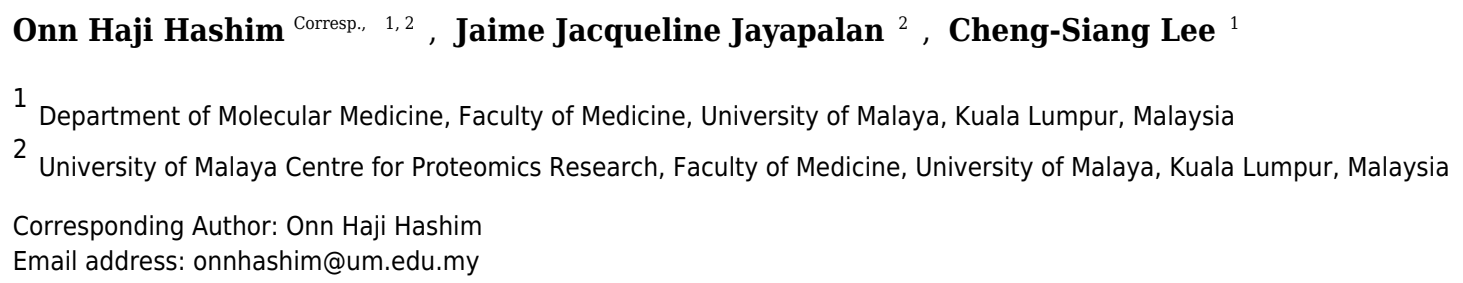

In recent years, the use of lectins for screening of potential biomarkers has gained increased importance in cancer research, given the development in glycobiology that highlights altered structural changes of glycans in cancer associated processes. Lectins, having the properties of recognizing specific carbohydrate moieties of glycoconjugates, have become an effective tool for detection of new cancer biomarkers in complex bodily fluids and tissues. The specificity of lectins provides an added advantage of selecting peptides that are differently glycosylated and aberrantly expressed in cancer patients, many of which are not possibly detected using conventional methods because of their low abundance in bodily fluids. When coupled with mass spectrometry, research utilizing lectins, which are mainly from plants and fungi, has led to identification of numerous potential cancer biomarkers that may be used in the future. This article reviews lectinbased methods that are commonly adopted in cancer biomarker discovery research. 
1

2

3

4

5

6

7

REVIEW ARTICLE

\title{
Lectins: An Effective Tool for Screening of Potential Cancer Biomarkers
}

\author{
Onn Haji Hashim ${ }^{1,2}$, Jaime Jacqueline Jayapalan ${ }^{2}$ and Cheng-Siang Lee ${ }^{1}$
}

\author{
${ }^{1}$ Department of Molecular Medicine, Faculty of Medicine, University of Malaya, 50603 \\ Kuala Lumpur, Malaysia \\ ${ }^{2}$ University of Malaya Centre for Proteomics Research, Faculty of Medicine, University of \\ Malaya, 50603 Kuala Lumpur, Malaysia
}

Corresponding author: Onn Haji Hashim, onnhashim@um.edu.my

3

\section{Abstract}

6

In recent years, the use of lectins for screening of potential biomarkers has gained increased importance in cancer research, given the development in glycobiology that highlights altered structural changes of glycans in cancer associated processes. Lectins, having the properties of recognizing specific carbohydrate moieties of glycoconjugates, have become an effective tool for detection of new cancer biomarkers in complex bodily fluids and tissues. The specificity of lectins provides an added advantage of selecting peptides that are differently glycosylated and aberrantly expressed in cancer patients, many of which are not possibly detected using conventional methods because of their low abundance in bodily fluids. When coupled with mass spectrometry, research utilizing lectins, which are mainly from plants and fungi, has led to identification of numerous potential cancer biomarkers that may be used in 
the future. This article reviews lectin-based methods that are commonly adopted in cancer biomarker discovery research.

\section{Biology of lectins}

Lectins are carbohydrate binding proteins which are found ubiquitously in nature. The term 'lectin' originates from the Latin word legere, which means to choose or to select (Boyd and Shapleigh, 1954). By binding to carbohydrates, lectins serve diverse biological functions.

Plant lectins, which typically cause agglutination of certain animal cells, play important roles in defense against invasion of virus, bacteria or fungi (Dias et al., 2015). They are also believed to mediate symbiosis relationship between plants and microorganisms (De Hoff et al., 2009), and some may be involved in regulatory and signaling pathways in plant cells (Chen et al., 2002).

Lectins have initially been classified based on their binding to different glycan structures. They were categorized either as galactose, $\mathrm{N}$-acetylglucosamine (GlcNAc), $\mathrm{N}$ acetylgalactosamine (GalNAc), glucose, L-fucose, mannose, maltose, sialic acid-specific or complex glycan-binding lectins (Lis and Sharon, 1986). Later, they were also classified based on the characteristics and numbers of their carbohydrate binding domains, namely merolectins, hololectins, chimerolectins and superlectins (Peumans et al., 2001). With the emergence of detailed structural properties of lectins being elucidated via the advancement of technology, this classification further evolved into that based on distinct protein folding, domains/structural similarities and evolutionary-relatedness of proteins (Peumans et al., 2001). Via this categorization, 12 different lectin families, which include Agaricus bisporus 
agglutinin homologues, amaranthins, class $\mathrm{V}$ chitinase homologues with lectin activity, cyanovirin family, Euonymus europaeus agglutinin family, Galanthus nivalis agglutinin family, jacalins, lysin motif domain, nictaba family, proteins with hevein domains, proteins with legume lectin domains and ricin-B family (Van Damme et al., 2008), have been derived.

Ricin is believed to be the first lectin discovered in the seeds of the castor bean plant, Ricinus communis, in 1888 (Sharon and Lis, 2004). Paradoxically, research on lectin only flourished several decades subsequent to ricin's discovery after James Sumner successfully purified a crystalline protein from jack bean (Canavalia ensiformis) in 1919. Sumner later showed that the protein caused agglutination of cells such as erythrocytes and yeast. The agglutinin, which is now known as concanavalin A or ConA, was also used for the first time to demonstrate binding of lectins to carbohydrate. To date, there are more than a thousand plant species that have been reported to possess lectins. Most of these lectins are in abundance in seeds (Lis and Sharon, 1986; Benedito et al., 2008), whilst some are found in leaves, roots, flower, sap, barks, rhizomes, bulbs, tubers and stems (Dias et al., 2015). Because of their carbohydrate binding specificities, many lectins have been increasingly applied in different areas of medical research and therapy (Table 1).

Table 1 Summary of different applications of lectins in medical research and therapy

\begin{tabular}{ll}
\hline \multicolumn{1}{c}{ Lectin applications } & \multicolumn{1}{c}{ Reference } \\
\hline Antibacterial agent & $\begin{array}{l}\text { Saha et al., 2014; Dias Rde et } \\
\text { al., 2015 }\end{array}$ \\
Antifungal agent & Klafke et al., 2013; Regente et \\
al., 2014 \\
Antiparasitic agent & Kobata-Kudo et al., 2005; \\
& Heim et al., 2015
\end{tabular}


Antiviral agent

Biomarker for disease detection and monitoring

Drug delivery

Induction of immunological and inflammatory response

Inhibition of cancer cell adhesion

Inhibition of cancer cell growth / antitumor agent

Promotion of healing in cutaneous wounds
Lusvarghi and Bewley, 2016;

Monteiro and Lepenies, 2017

This review article

Leong et al., 2011; Neutsch et

al., 2013

Singh et al., 2011; Ditamo et

al., 2016

Redondo and Alvarez-

Pellitero, 2010; Siva et al., 2014

Jebali et al., 2014; Quiroga et

al., 2015; Dan et al., 2016

Brustein et al., 2012;

Coriolano et al., 2014

66

A biomarker is defined as "a characteristic that is objectively measured and evaluated as an indicator of normal biological processes, pathogenic processes or pharmacologic responses to a therapeutic intervention" (Biomarkers Definition Working Group, 2001). Hence, simple parameters from pulse and blood pressure to protein constituents of cells, tissues, blood and other biofluids are classified as biomarkers. Bodily fluids that have been mined for cancer biomarkers thus far include serum/plasma, urine, saliva and other tissue-specific fluids such as seminal fluid, cerebrospinal fluid, bone marrow aspirates, etc. Cancer biomarkers are useful for early detection, diagnosis and prognosis of the disease. They are also heavily relied on in management of patients, and assessment of pharmacodynamics of drugs, risk, as well as recurrence of the disease. 
Efforts in the search for new cancer biomarkers remain active even in the present day.

80

Currently, there are only a handful of cancer biomarkers that are commonly being used in the clinical setting (Table 2), most of which have been officially approved by the US Food and Drug Administration (FDA) for clinical use (Füzéry et al., 2013). More are definitely needed for improved detection and diagnosis, particularly when the reliability of many of the FDA approved biomarkers remains a problem due to their limited levels of sensitivity and specificity. For example, CA-125 which is used as a biomarker for ovarian cancer, is also often elevated in other cancers such as those of the breast (Norum et al., 2001), lung (Salgia et al., 2001) and colon or rectum (Thomas et al., 2015). Similarly, prostate specific antigen (PSA), a tissue-specific serum protein that is used in the diagnosis of prostate cancer, is also commonly increased in sera of patients with benign prostatic hyperplasia, thus, posing difficulties in clinically differentiating the two different conditions (Barry, 2001; Thompson et al., 2004). These limitations, together with the recent development of various state-of-theart methodologies including genomics, proteomics and bioinformatics, have consequentially propelled research towards identification of new cancer biomarkers that are more sensitive and specific.

Table 2 List of commonly used tumor markers in clinical practice.

\begin{tabular}{lllll}
\hline \multicolumn{1}{c}{ Biomarker } & Glycosylated & Cancer type & \multicolumn{1}{c}{ Specimen } & \multicolumn{1}{c}{ Clinical use } \\
\hline $\begin{array}{l}\text { Alpha-feto protein } \\
\text { (AFP) }\end{array}$ & Yes & Testicular & $\begin{array}{l}\text { Serum/plasma; } \\
\text { Amniotic fluid }\end{array}$ & $\begin{array}{l}\text { Management of } \\
\text { cancer }\end{array}$ \\
AFP-L3\% & Yes & Hepatocellular & Serum & Risk assessment \\
$\begin{array}{l}\text { Beta-2- } \\
\text { microglobulin }\end{array}$ & Yes & Blood cells & Serum, Urine, & Monitoring \\
(B2M) & & & Cerebrospinal & progression and \\
Bladder tumor- & Unknown & Bladder & Urine & Monitoring disease
\end{tabular}


associated antigen

\begin{tabular}{|c|c|c|c|c|}
\hline CA $15-3$ & Yes & Breast & Serum/plasma & $\begin{array}{l}\text { Monitoring disease; } \\
\text { Response to therapy }\end{array}$ \\
\hline CA 19-9 & $\mathrm{Yes}^{2}$ & Pancreatic & Serum/plasma & Monitoring disease \\
\hline CA 27-29 & Yes & Breast & Serum & $\begin{array}{l}\text { Monitoring disease; } \\
\text { Response to therapy }\end{array}$ \\
\hline CA 125 & Yes & Ovarian & Serum/plasma & $\begin{array}{l}\text { Monitoring disease; } \\
\text { Response to therapy }\end{array}$ \\
\hline $\begin{array}{l}\text { Carcinoembryonic } \\
\text { antigen (CEA) }\end{array}$ & Yes & Colon & Serum/plasma & $\begin{array}{l}\text { Monitoring disease; } \\
\text { Response to therapy }\end{array}$ \\
\hline $\mathrm{c}-\mathrm{Kit}$ & Yes & $\begin{array}{l}\text { Gastrointestinal } \\
\text { stromal tumors }\end{array}$ & Tissue & $\begin{array}{l}\text { Detection of tumor; } \\
\text { Patient selection }\end{array}$ \\
\hline $\begin{array}{l}\text { EpCAM, CD45, } \\
\text { cytokeratins } 8, \\
18+, 19+\end{array}$ & Yes & Breast & Whole blood & $\begin{array}{l}\text { Monitoring } \\
\text { progression and } \\
\text { survival }\end{array}$ \\
\hline $\begin{array}{l}\text { Epidermal growth } \\
\text { factor receptor } \\
\text { (EGFR) }\end{array}$ & Yes & Colon & Tissue & Therapy selection \\
\hline $\begin{array}{l}\text { Estrogen receptor } \\
\text { (ER) }\end{array}$ & Yes & Breast & Tissue & $\begin{array}{l}\text { Prognosis; } \\
\text { Response to therapy }\end{array}$ \\
\hline HER2/NEU & Yes & Breast & Serum; Tissue & $\begin{array}{l}\text { Monitoring } \\
\text { progression; } \\
\text { Therapy selection }\end{array}$ \\
\hline $\begin{array}{l}\text { Human chorionic } \\
\text { gonadotropin }\end{array}$ & Yes & Testicular & Serum & Staging of cancer \\
\hline $\begin{array}{l}\text { Human } \\
\text { epididymis } \\
\text { protein } 4(\mathrm{HE} 4)\end{array}$ & Yes & Ovarian & Serum & $\begin{array}{l}\text { Monitoring } \\
\text { progression and } \\
\text { recurrence }\end{array}$ \\
\hline $\begin{array}{l}\text { Fecal occult blood } \\
\text { (haemoglobin) }\end{array}$ & Yes & Colorectal & Feces & Detection of tumor \\
\hline $\begin{array}{l}\text { Fibrin/fibrinogen } \\
\text { degradation } \\
\text { product (DR-70) }\end{array}$ & Yes & Colorectal & Serum & Monitoring disease \\
\hline $\begin{array}{l}\text { Free prostate } \\
\text { specific antigen }\end{array}$ & Yes & Prostate & Serum & $\begin{array}{l}\text { Screening for } \\
\text { disease }\end{array}$ \\
\hline $\begin{array}{l}\text { Nuclear mitotic } \\
\text { apparatus protein } \\
\text { (NuMA, NMP22) }\end{array}$ & Yes & Bladder & Urine & $\begin{array}{l}\text { Diagnosis and } \\
\text { monitoring disease }\end{array}$ \\
\hline p63 protein & No & Prostate & Tissue & $\begin{array}{l}\text { Differential } \\
\text { diagnosis }\end{array}$ \\
\hline $\begin{array}{l}\text { Plasminogen } \\
\text { activator inhibitor }\end{array}$ & Yes & Breast & Tissue & $\begin{array}{l}\text { Monitoring disease; } \\
\text { Therapy selection }\end{array}$ \\
\hline
\end{tabular}

(PAI-1) 


\begin{tabular}{|c|c|c|c|c|}
\hline $\begin{array}{l}\text { Progesterone } \\
\text { receptor (PR) }\end{array}$ & Yes & Breast & Tissue & Therapy selection \\
\hline Pro2PSA & Yes & Prostate & Serum & $\begin{array}{l}\text { Discriminating } \\
\text { cancer from benign } \\
\text { disease }\end{array}$ \\
\hline $\begin{array}{l}\text { Thyroglobulin } \\
\text { (Tg) }\end{array}$ & Yes & Thyroid & Serum/plasma & Monitoring disease \\
\hline Total PSA & Yes & Prostate & Serum & $\begin{array}{l}\text { Diagnosis and } \\
\text { monitoring disease }\end{array}$ \\
\hline $\begin{array}{l}\text { Urokinase } \\
\text { plasminogen } \\
\text { activator (uPA) }\end{array}$ & Yes & Breast & Tissue & $\begin{array}{l}\text { Monitoring disease; } \\
\text { Therapy selection }\end{array}$ \\
\hline
\end{tabular}

$97{ }^{1}$ Also used in prenatal diagnosis of birth defects, a non-cancer application.

$98{ }^{2} \mathrm{~A}$ tetrasaccharide carbohydrate that is usually attached to $O$-glycans on the surface of cells. 99

100

Amongst bodily fluids that have been mined for cancer biomarkers, serum/plasma is most popular. Serum or plasma has the advantage of being routinely sampled in clinical investigations. However, the extreme complexity and broad dynamic range of protein abundance in serum and plasma pose a formidable challenge in research screening for potential cancer biomarkers, which mostly comprise low abundance glycoproteins. Because of this, many cancer biomarker exploratory studies involving serum or plasma often involved enrichment and/or pre-fractionation of the samples using techniques such as immunodepletion (Preito et al., 2014), immunoprecipitation (Lin et al., 2013) and sizeexclusion chromatography (Hong et al., 2012). However, the use of such techniques, despite their wide applications in biomarker discovery investigations, is generally unable to make a 
115 Interestingly, the majority of cancer biomarkers that are currently being used in the clinical

116 settings are glycoproteins, which are structurally altered in their glycan moieties and

117 aberrantly expressed (Henry and Hayes, 2012). However, only alpha-fetoprotein (AFP) and

118 CA15-3 are clinically monitored for their glycan changes in the therapy for hepatocellular

119 carcinoma and breast cancer, respectively. The other cancer biomarkers are being monitored

120 for their total protein levels (Kuzmanov et al., 2013). Indeed, changes in glycosylation are

121 believed to be a main feature in oncogenic transformation as glycans are known to be

122 continuously involved in cancer evolving processes, such as cell signaling, angiogenesis,

123 cell-matrix interactions, immune modulation, tumor cell dissociation and metastasis.

124 Glycosylation changes that are commonly associated with cancer transformation include

125 sialylation, fucosylation, increased GlcNAc-branching of $\mathrm{N}$-glycans, and overexpression of

126 truncated mucin-type $O$-glycans (Pinho and Reis, 2015). Hence, it is not surprising that

127 lectin-based approaches are becoming more popular in studies screening for novel cancer

128 biomarkers. Table 3 shows a list of lectins that have been used in cancer biomarker

129 discovery research. In the following sections of this review, the applications of lectins in

130 cancer biomarker discovery, including immobilized lectin affinity chromatography, enzyme-

131 linked lectin assay, lectin histochemistry, lectin blotting and lectin array, are addressed. For

132 lectin-based biosensor analysis, readers are recommended to refer to separate review articles

133 (Pihíková et al., 2015; Coelho et al., 2017). 


\begin{tabular}{|c|c|c|c|c|}
\hline Lectin & Abbreviation & Specificity & Glycan Linkage & References \\
\hline $\begin{array}{l}\text { African legume (Griffonia } \\
\text { (Bandeiraea) simplicifolia) lectin-I }\end{array}$ & GSLI (BSLI) & $\alpha$-Gal; $\alpha$-GalNAc & $O$-linked & Lescar et al., 2002 \\
\hline $\begin{array}{l}\text { Asparagus pea (Lotus } \\
\text { tetragonolobus) lectin }\end{array}$ & LTL & $\begin{array}{l}\text { Fuc } \alpha 1-3(G a l \beta 1-4) \text { GlcNAc, Fuc } \alpha 1- \\
2 \text { Gal } \beta 1-4 G l c N A c\end{array}$ & $N$-linked & $\begin{array}{l}\text { Pereira and Kabat, 1974; } \\
\text { Yan et al., } 1997\end{array}$ \\
\hline Koji (Aspergillus oryzae) lectin & AOL & $\alpha 1,6$-fucosylated & $N$-linked & Matsumura et al., 2007 \\
\hline $\begin{array}{l}\text { Castorbean (Ricinus communis) } \\
\text { agglutinin }\end{array}$ & $\mathrm{RCA}$ & Gal $\beta 1-4 G l c N A c$; terminal $\beta$-D-Gal & $N$-linked & $\begin{array}{l}\text { Harley and Beevers 1986; } \\
\text { Wang et al., } 2011\end{array}$ \\
\hline $\begin{array}{l}\text { Champedak (Artocarpus integer) } \\
\text { galactose binding lectin }\end{array}$ & CGB & Gal; GalNAc & $O$-linked & $\begin{array}{l}\text { Hashim et al., 1991; } \\
\text { Gabrielsen et al., } 2014\end{array}$ \\
\hline $\begin{array}{l}\text { Champedak (Artocarpus integer) } \\
\text { mannose binding lectin }\end{array}$ & $\mathrm{CMB}$ & Man & $N$-linked & $\begin{array}{l}\text { Lim et al., 1997; } \\
\text { Gabrielsen et al., } 2014\end{array}$ \\
\hline $\begin{array}{l}\text { Daffodil (Narcissus pseudonarcissus) } \\
\text { lectin }\end{array}$ & NPL & $\begin{array}{l}\alpha \text {-Man, prefers polymannose } \\
\text { structures containing } \alpha-1,6 \text { linkages }\end{array}$ & $N$-linked & $\begin{array}{l}\text { Kaku et al., 1990; } \\
\text { Lopez et al., } 2002\end{array}$ \\
\hline $\begin{array}{l}\text { Elderberry (Sambucus nigra) } \\
\text { agglutinin }\end{array}$ & SNA & Neu5Aca2-6Gal(NAc)-R & $N$ - and $O$-linked & $\begin{array}{l}\text { Shibuya et al., 1987; } \\
\text { Silva et al., } 2017\end{array}$ \\
\hline $\begin{array}{l}\text { Gorse or furze (Ulex europaeus) seed } \\
\text { agglutinin-I }\end{array}$ & UEA-I & Fuc $\alpha 1-2$ Gal-R & $N$ - and $O$-linked & $\begin{array}{l}\text { Holthofer et al., 1982; } \\
\text { Raj Bharath and Krishnan, } \\
2016\end{array}$ \\
\hline $\begin{array}{l}\text { Jackbean (Canavalia ensiformis) } \\
\text { lectin }\end{array}$ & ConA & $\alpha$-Man; $\alpha$-Glc & $N$-linked & Percin, et al., 2012 \\
\hline $\begin{array}{l}\text { Jackfruit (Artocarpus heterophyllus) } \\
\text { lectin }\end{array}$ & Jacalin & Gal; GalNAc & $O$-linked & $\begin{array}{l}\text { Kabir, 1995; } \\
\text { Jagtap and Bapat, } 2010\end{array}$ \\
\hline Lentil (Lens culinaris) hemagglutinin & $\mathrm{LcH}$ & $\begin{array}{l}\text { Man; Glc (Affinity enhanced with } \alpha \text { - } \\
\text { Fuc attached to } N \text {-acetylchitobiose) }\end{array}$ & $N$-linked & $\begin{array}{l}\text { Howard et al., 1971; } \\
\text { Chan et al., } 2015\end{array}$ \\
\hline Amur maackia (Maackia amurensis) & MAL II & 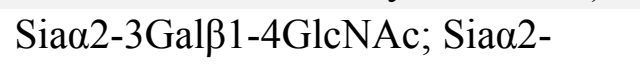 & $N$ - and $O$-linked & Konami et al., 1994; \\
\hline
\end{tabular}


lectin II

Orange peel fungus (Aleuria

aurantia) lectin

Peanut (Arachis hypogaea) agglutinin

Chinese green dragon (Pinellia

pedatisecta) agglutinin

Poke weed (Phytolacca americana)

mitogen lectin

Red kidney bean (Phaseolus

vulgaris) lectin

Thorn-apple (Datura stramonium)

lectin

Wheat germ (Triticum vulgaris)

agglutinin

White button mushroom (Agaricus

bisporus) lectin
3Gal $\beta 1-3 \mathrm{GalNAc}$

AAL Fuc $\alpha 1-6$ GlcNAc; Fuc $\alpha 1-3 L a c N A c$

PNA Galß1-3GalNAc; Gal

PPA Man

PWM GlcNAc oligomers

PHA-L Bisecting GlcNAc

DSL (GlcNAc $\beta 4) n$

WGA GlcNAc $\beta 1-4 G l c N A c \beta 1-4 G l c N A c ;$

Neu5Ac

ABL GalNAc; Galß1,3GalNAc (T

antigen); sialyl-Gal $\beta$
Geisler and Jarvis, 2011

$\mathrm{N}$ - and $\mathrm{O}$-linked Hassan et al., 2015

O-linked Chacko and Appukuttan,

2001; Vijayan, 2007

$N$-linked Li et al., 2014

N-linked Kino et al., 1995;

Ahmad et al., 2009

$N$-linked $\quad$ Kaneda et al., 2002;

Movafagh et al., 2013

$N$-linked $\quad$ Yamashita et al., 1987;

Abbot et al., 2010

Nagata and Burger, 1972;

Parasuraman et al., 2014

Nakamura-Tsuruta et al.,

2006; Hassan et al., 2015

138 
$140 \quad$ Immobilized-lectin affinity chromatography

141 Immobilized-lectin affinity chromatography is a method for separation of glycoproteins

142 based on a highly specific interaction between a lectin, which is immobilized onto a chosen

143 matrix, and its carbohydrate ligands (Hage et al., 2012). The technique, when complemented

144 with mass spectrometry analysis, provides a useful tool in research aiming to identify

145 potential cancer biomarkers (Figure 1). By comparing bodily fluid samples of control

146 subjects with those from patients with cancer, glycoproteins that are aberrantly expressed or

147 differently glycosylated from the resulting glycoprotein-enriched eluates can be easily

148 identified. Immobilized-lectin affinity chromatography is currently one of the most widely

149 employed techniques for enrichment of glycoproteins in cancer biomarker research. 


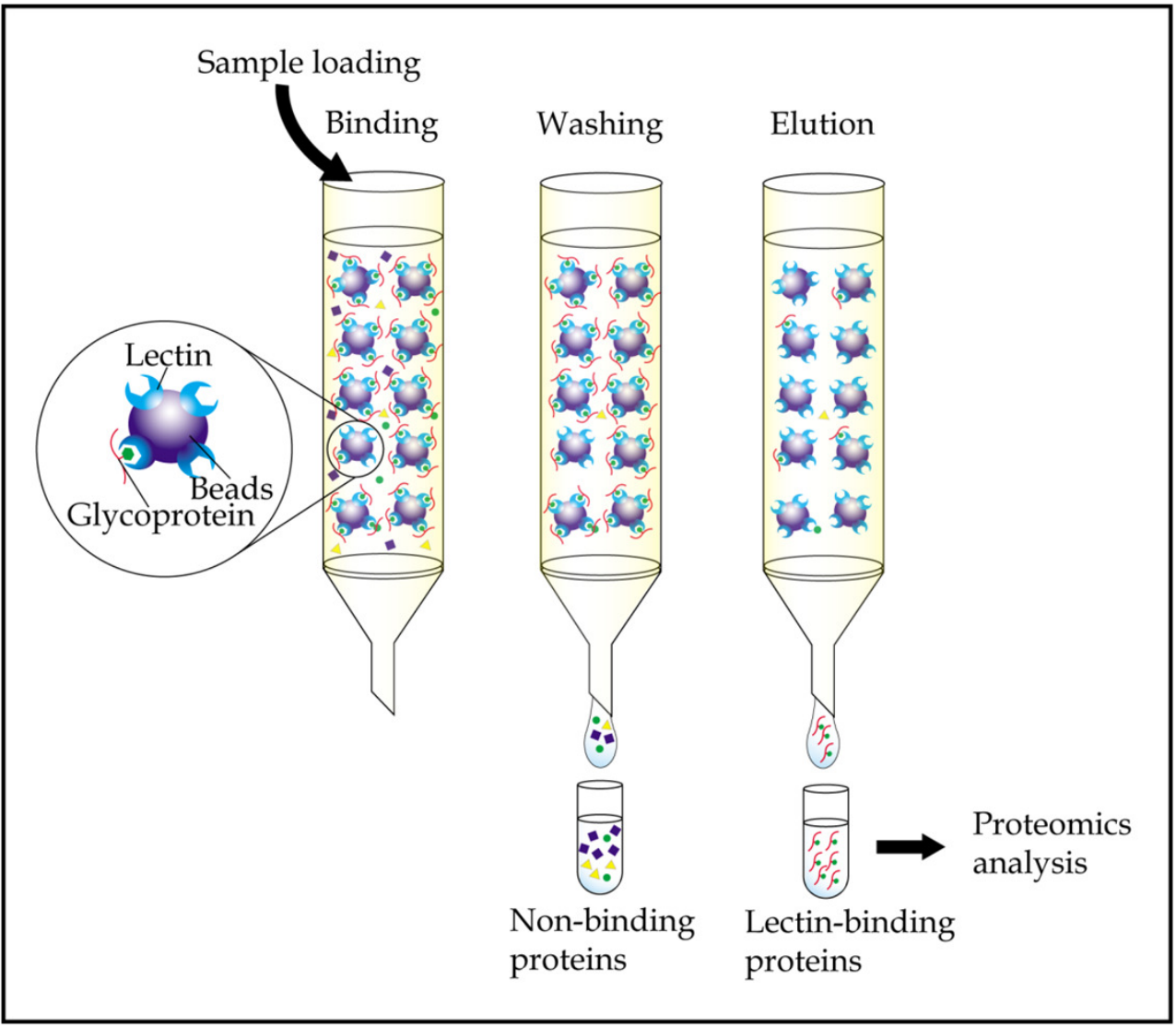

152 Figure 1 General workflow of immobilized-lectin affinity chromatography. Bodily fluid 153 of cancer patients can be assayed for potential cancer biomarkers by running it through a 154 chromatography column packed with a gel matrix that is conjugated with a lectin of interest. 155 Non-binding proteins are then washed out, whilst bound glycoproteins are eluted using specific 156 carbohydrate solutions. The lectin bound glycoproteins are finally identified using proteomics 157 analysis.

By using immobilized-ConA, followed by separation by 2-dimensional gel electrophoresis (2-DE), Rodriguez-Pineiro et al. (2004) were able to profile serum samples of patients with colorectal cancer and showed significant altered expression of several $\mathrm{N}$ glycosylated proteins that were identified by mass spectrometry. These included upregulated expression of haptoglobin and lowered expression of antithrombin-III, clusterin, 
164 inter-alpha-trypsin inhibitor heavy chain H4, beta-2-glycoprotein I and coagulation factor

165 XIII B chain in the colorectal cancer patients relative to healthy donors. Similarly, Seriramalu et al. (2010) reported the lowered expression of complement factor B and alpha-2 macroglobulin in patients with nasopharyngeal carcinoma relative to controls using the champedak mannose binding lectin. In the case of $O$-glycosylated proteins, considerable studies have been reported using champedak galactose binding (CGB) lectin, which has a unique characteristic of binding to the $O$-glycan structures of glycoproteins ( $\mathrm{Abdul}$ Rahman et al., 2002) in serum and urine samples. Cancers that have been investigated using immobilized-CGB lectin include endometrial cancer (Mohamed et al., 2008) and prostate cancer (Jayapalan et al., 2012). However, most of the serum and urine $\mathrm{N}$ - and $\mathrm{O}$ glycosylated proteins that were isolated using the immobilized-lectin affinity chromatography are not directly cancer associated but the body's highly abundant acutephase reactant proteins (Pang et al., 2010). chromatography for identification of site-specific glycosylation using mass spectrometry techniques have been reported in studies in search of potential cancer biomarkers. Enrichment of core fucosylated peptides using Lens culinaris agglutinin (LCA) after trypsin digestion of glycoproteins, followed by endo F3 partial deglycosylation and nano LCMS/MS methodologies, has led to identification of glycopeptides that can potentially be used as diagnostic biomarkers for pancreatic cancer (Tan et al., 2015). Similarly, enrichment of trypsin-digested glycopeptides using Aleuria aurantia lectin (AAL) that was immobilized onto agarose gel, followed by analysis using LC/MS, has resulted in identification of alpha1-acid glycoprotein with multi-fucosylated tetraantennary glycans as a potential marker for 
187 hepatocellular carcinoma (Tanabe et al., 2016). In another study, the Sambucus niagra agglutinin (SNA) affinity column was used to separate various glycoforms of serum PSA according to the types of sialic acid linkages (Llop et al., 2016). This has resulted in identification of $\alpha 2,3$-sialylated PSA as a marker for discriminating patients with high-risk with higher levels of sensitivity and specificity.

Another variant of immobilized-lectin affinity chromatography used in cancer biomarker research is multi-lectin affinity chromatography. Since no single lectin is able to isolate the complete complement of a glycoprotein, a multi-lectin affinity chromatography is gaining popularity because of its greater coverage and depth of analyses. Using a combination of four different types of lectins, including ConA, SNA, Phaseolus vulgaris agglutinin (PHA) and Ulex europaeus agglutinin (UEA), for sequential multi-lectin affinity chromatography in silica-based microcolumns and nano-LC/MS/MS for identification of proteins, Madera et al. (2007) successfully profiled glycoproteins from microliter volumes of serum. Along the same line but using ConA, wheat germ agglutinin (WGA) and jacalin that were integrated into an automated HPLC platform and immuno-depleted serum samples, Zeng et al. (2011) demonstrated a comprehensive detection and changes in the abundances of posttranslationally modified breast cancer-associated glycoproteins. To facilitate a cascading flow of samples from column to column for simultaneous and efficient capturing and enrichment of fucosylated proteins, Selvaraju and El Rassi (2013) developed of a platform, which comprised multi-lectin columns driven by HPLC pumps for elucidating differential expression of serum fucome between cancer-free and breast cancer subjects. This method surpasses issues such as loss of samples due to sample preparation and processing (e.g., 
210 dilution) as well as other experimental biases that commonly occur when using other

211 techniques.

Recently, Miyamoto et al. (2016) reported a comprehensive proteomic profiling of ascites

213 fluid obtained from patients with metastatic ovarian cancer enriched by differential binding

214 to multiple lectins, including ConA, AAL and WGA. Alpha-1-antichymotrypsin, alpha-1-

215 antitrypsin, ceruloplasmin, fibulin, fibronectin, hemopexin, haptoglobin and lumican

216 appeared more abundant in ascites of the patients compared to controls. Further glycopeptide

217 analysis identified unusual $N$ - and $O$-glycans in clusterin, fibulin and hemopexin

218 glycopeptides, which may be important in metastasis of ovarian cancer. Similar use of multi-

219 lectin affinity chromatography for enrichment of $N$-linked glycoproteins by Qi et al. (2014)

220 has successfully identified human liver haptoglobin, carboxylesterase 1 and procathepsin D

221 as candidate biomarkers associated with development and progression of hepatocellular

222 carcinoma. Whilst the concentrations of human liver haptoglobin and carboxylesterase 1

223 were consistently lower, higher concentration of procathepsin D was detected in the liver

224 cancer tissues. Further in-depth analysis projected the promising use of procathepsin D as

225 serological biomarker for diagnosis of hepatocellular carcinoma. immunosorbent assay but uses lectin as one of the reagents instead of antibody. This method was introduced by McCoy Jr. et al. (1983) in the early eighties. In a direct assay, samples that contain glycoconjugates may be coated directly onto the wells of a microtiter plate, 

structures (Figure 2, panel A). The enzyme converts a colorless substrate solution to a colored product, that is then measured using a spectrophotometer, and whose intensity is used to estimate the levels of the coated glycoconjugates. Depending on the structures of assay has been used in a plethora of research including those of cancer biomarkers

(A)

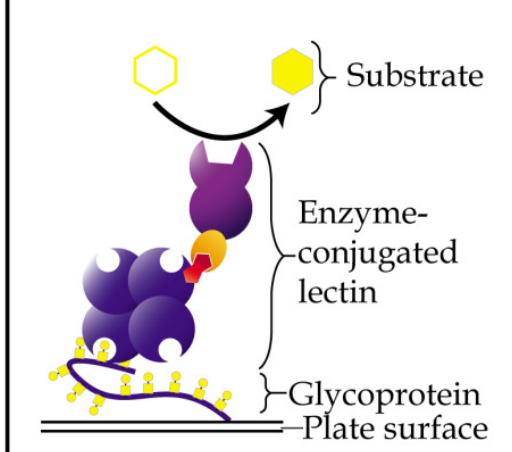

(B)

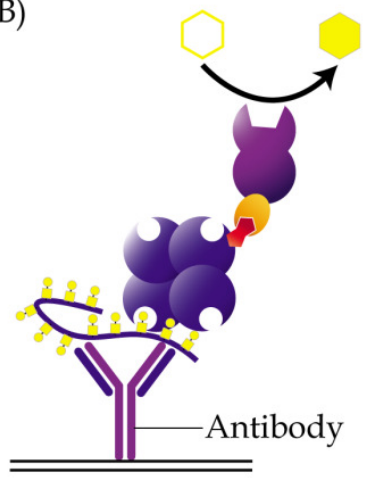

(C)

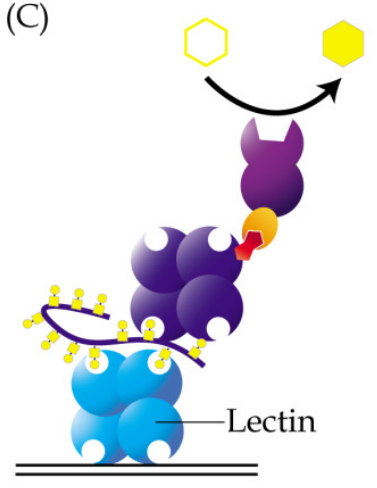

Figure 2 Different approaches of enzyme-linked lectin assay. (A) In the direct assay, coating of samples is performed directly onto the surface of a microtiter plate, followed by addition of enzyme-conjugated lectin. (B) In the hybrid assay, antibody is instead coated onto the plate to capture specific glycoproteins of interest, prior to addition of the enzymeconjugated lectin. (C) Sandwich enzyme-linked lectin assay is an alternative method involving two different lectins. The first lectin is coated onto plates and used as a capturing reagent, whilst the second lectin is used as detection reagent. For all the aforementioned methods, 
251 glycoproteins are usually detected using a lectin that is conjugated to an enzyme, which then converts a specific substrate into a colored product.

Based on their earlier study that identified a predominantly high molecular weight glycoprotein that binds to peanut lectin (PNA) in the sera of patients with pancreatic cancer, Ching and Rhodes (1989) developed a direct enzyme-linked PNA assay for diagnosis of pancreatic cancer. Results obtained from the lectin-based assay were apparently found to be comparable with those derived from using CA19-9 radioimmunoassay, in terms of sensitivity and specificity for pancreatic cancer. In another study, Reddi et al. (2000) reported the use of similar enzyme-linked PNA assay to estimate the levels of Thomsen-Friendenreich antigen (T-Ag) in sera of patients with squamous cell carcinoma of the uterine cervix, before and after radiotherapy. The study demonstrated significantly higher levels of T-Ag in the sera of the uterine cervical cancer patients compared to normal individuals, and that the expression of PNA-binding T-Ag were directly proportional to the aggressiveness of the cancer. In a study by Dwek et al., (2010), the specificity of UEA-1 lectin to $\alpha 1,2-$ linked fucose sites was capitalized for detection of fucosylated serum free PSA in a direct enzyme-linked lectin assay. Their results demonstrated higher levels of fucosylated serum free PSA in patients with prostate cancer compared to those with benign prostatic hyperplasia.

Aside from sera, direct enzyme-linked lectin assay has also been used in the analysis of tissue lysate glycoproteins. In a recent study of breast cancer tissue lysates of different stages, Wi et al. (2016) demonstrated increased interaction with ConA, Ricinus communis Agglutinin I, AAL and Maackia amurensis lectin II (MAL II), relative to normal tissue specimen of the same subjects. This is generally interpreted to show enhanced 
274

275

276

277

278

279

280

281

282

283

284

285 mannosylation, galactosylation, sialylation and fucosylation of glycoproteins in the breast cancer tissues. In another study, Kim et al. (2014) have shown lower levels of fucosylation and sialylation of cytosolic intracellular glycoproteins in cancerous human cervical tissues compared to normal tissue specimens from the same subjects using AAL and SNA lectins, respectively. However, the levels of mannosylation, which was assayed using ConA, were not significantly different between cancer tissues and normal specimens.

Subtle changes to the classical enzyme-linked lectin assay protocol have been introduced over the years. An example is the combined use of antibody with lectin to enable detection of glycosylation on a specific protein (Kim et al., 2008). In this case, an antibody may be coated directly onto the wells of a microtiter plate, which will allow pre-capturing of a protein of interest from complex samples (Figure 2, panel B). A lectin is then added and let on to bind with the glycan structures of the protein. In this method, prior purification of a glycoprotein is not needed as the antibody utilized specifically isolates the protein of interest from within the samples. This method is also more suitable for glycoprotein antigens, which are generally hydrophilic and cannot be well-coated onto a microtiter plate. The disadvantage of this approach is that a lectin may directly interact with glycan chains of the antibody used, which would then result in high background readings.

To solve the issue of the non-specific direct interaction of lectin to antibodies in enzymelinked lectin assays, Takeda et al. (2012) have instead used the Fab fragment of anti-human haptoglobin IgG antibody and biotinylated AAL lectin for sandwich detection of fucosylated haptoglobin. Their results showed that the levels fucosylated haptoglobin were significantly associated with overall and relapse-free survival, distant metastasis, clinical stage, and curability of patients with colorectal cancer. When Kaplan-Meier analysis was performed on 
patients after more than 60 months of surgery, positive cases of fucosylated-haptoglobin showed poor prognosis compared with fucosylated-haptoglobin negative cases. This leads to the suggestion of fucosylated haptoglobin as a prognostic marker in addition to CEA for colorectal cancer. Along the same line, Jin et al. (2016) have instead used protein A as the glycoproteins and biotinylated-antibodies to detect clusterin, complement factor $\mathrm{H}$, capturing reagent and AAL lectin as detection probe, for assessment of fucosylated circulating antibodies in cervical intraepithelial neoplasia and cervical cancer. Significantly lower levels of fucosylated circulating immunoglobulins were shown in female patients with cervical cancer compared to those with cervical intraepithelial neoplasia or normal subjects. hemopexin and vitamin D-binding protein to validate the altered levels of the respective glycoproteins in sera of patients with ovarian cancer. The results were consistent with their data that was previously generated using isobaric chemical labeling quantitative strategy. In a similar strategy, Liang et al. (2015) have used Bandeiraea (Griffonia) simplicifolia-I (BSI), AAL and Poke weed mitogen (PWM) lectins as capturing reagents and biotinylated antihuman $\alpha$-1-antitrypsin polyclonal antibody in a sandwich enzyme-linked lectin combination assay to validate results of their lectin microarray analysis of serum samples of patients with lung cancer. While galactosylated $\alpha$-1-antitrypsin was shown to demonstrate remarkable discriminating capabilities to differentiate patients with non-small-cell lung cancer from benign pulmonary diseases, their fucose- and poly-LacNAc-containing counterparts may be used to discriminate lung adenocarcinoma from benign diseases or other lung cancer subtypes, and small-cell lung cancer from benign diseases, respectively. 
In a slightly different context, Lee et al. (2013) have developed a sandwich enzyme-

320 linked assay that uses two different lectins that both bind to $O$-glycan structures of

321 glycoproteins (Figure 2, panel C). The assay, which uses CGB lectin as capturing coated

322 reagent and enzyme-conjugated jacalin as detection probe, was primarily designed to

323 measure the levels of mucin-type $O$-glycosylated proteins in serum samples. When the assay

324 was applied on sera of patients with stage 0 and stage I breast cancer as well as those of

325 normal control women, significantly higher levels of $O$-glycosylated proteins were detected

326 in both groups of breast cancer patients (Lee et al., 2016). The specificity and sensitivity of

327 the assay were further improved when the same serum samples were subjected to perchloric

328 acid enrichment prior to the analysis. Further characterization of the perchloric acid isolates

329 by gel-based proteomics detected significant altered levels of plasma protease $\mathrm{C} 1$ inhibitor

330 and proteoglycan 4 in both stage 0 and stage I breast cancer patients compared to the

331 controls. Their data suggests that the ratio of the serum glycoproteins may be used for

332 screening of early breast cancer.

Lectin histochemistry

335 Like immunohistochemistry, lectin histochemistry is a microscopy-based technique for

336 visualization of cellular components of tissues except that it uses lectin instead of antibodies.

337 Utilization of labelled lectins in the tissue staining procedure limits the technique to detection

338 of only glycan-conjugated components, as well as those whose glycan moieties are being

339 recognized specifically by the individual lectins. Unlike immunohistochemistry which

340 detects presence of specific antigens based on the specificities of antibodies used, lectin

341 histochemistry provides information concerning glycosylation processes within a tissue 
sample as well as their intracellular locations. This information can be very useful in the 343 characterization and/or detection of diseases.

In lectin histochemistry, labelling can be performed directly or indirectly (Roth, 2011).

345 In the direct labelled method, which is generally less sensitive than the direct method, lectins

346 are directly linked to fluorophores, enzymes, colloidal gold or ferritin, depending on the

347 microscopy involved (Figure 3, panel A). On the other hand, the indirect method involves

348 conjugation of lectins with biotin or digoxigenin, which may be detected using enzyme

349 linked-streptavidin or -anti-digoxigenin, respectively (Figure 3, panel B). Apparently, not all

350 chemicals can be used in the fixation and embedding of tissues in lectin histochemistry. For

351 example, the use of formaldehyde in fixation of tissue specimens is known to cause reduced

352 sensitivity of the Griffonia simplicifolia agglutinin, whilst ethanol-acetic acid fixation

353 improved its binding (Kuhlmann and Peschke, 1984). Paraffin, which causes denaturation of

354 proteins, is also known to result in attenuated binding of lectins due to sequestration of

355 carbohydrates in the glycoproteins that are denatured. However, this can be largely reversed

356 by removal of tissue-embedded paraffin using xylene or by trypsinization, which breaks the

357 protein cross-links and allows the lectins to bind more efficiently (Brooks and Hall, 2012). 


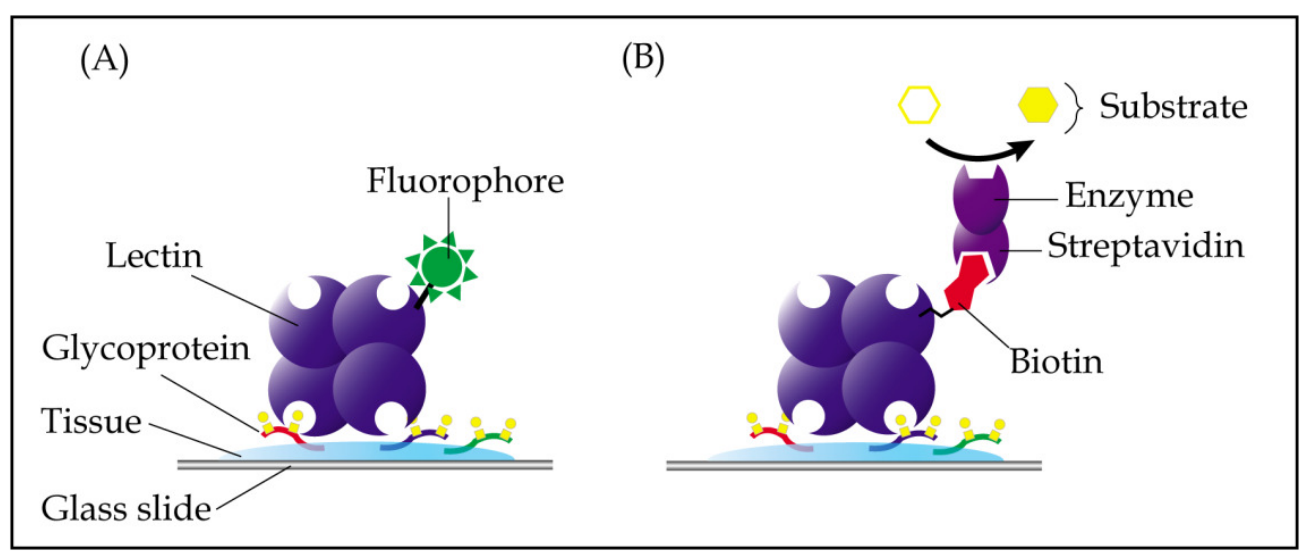

360

Figure 3 Common techniques in lectin histochemistry. Comparative staining of cancer versus normal tissues may highlight aberrant glycosylation of glycoproteins. (A) In the direct method, glycoproteins are detected in tissue specimens using a lectin that is covalently linked to fluorophores, enzymes, colloidal gold or ferritin. (B) The indirect labelled method, which is generally more sensitive, involves use of a lectin that is conjugated with a hapten, such as biotin or digoxigenin, which are then recognized using enzyme linked-streptavidin or -antidigoxigenin, respectively.

Lectin histochemistry has been extensively used in the study of glycosylation changes in cancer tissues. Two lectins have been found useful in distinguishing the different histological grades of mucoepidermoid carcinoma, the most common type of salivary gland cancer (Sobral et al., 2010). Whilst ConA was demonstrated to be able to stain all grades of mucoepidermoid carcinoma tissues, staining with UEA-I lectin showed direct correlation of malignancy with the intensity of staining. Another example is cholangiocarcinoma that is attributed to the river fluke infection that commonly occurs in Thailand. In the study of the parasite-induced cancer, Indramanee et al. (2012) have used multiple lectins to demonstrate aberrant glycosylation of glycoconjugates in paraffin-embedded liver tissues of patients with primary cholangiocarcinoma. Unique lectin staining patterns derived from the cancer 
378 patients, relative to non-tumorous tissues, can be utilized as early stage markers for the bile

379 duct cancer. Similarly, SNA has been proposed for use as a prognostic probe for invasive

380 ductal carcinoma based on the different staining patterns that were generated compared to

381 tissue sections of patients with stage 0 breast cancer, ductal carcinoma in situ (Dos-Santos et

382 al., 2014). In another histochemical study, eight different lectins have been used to identify

383 specific carbohydrates that may contribute to the progression of colorectal cancer

384 (Hagerbaumer et al., 2015). The results showed changes in the binding patterns of five of

385 the lectins during advancement of metastasis from adenoma to colorectal carcinoma.

386

$387 \quad$ Lectin blotting

388 Lectin blotting is an extension of western blotting that uses lectin instead of antibody to 389 detect glycoconjugates (Shan et al., 2001). As in western blotting, samples are similarly 390 resolved using polyacrylamide gel electrophoresis and transferred onto a polyvinylidene

391 fluoride (PVDF) or nitrocellulose membrane but detected using glycan-specific lectin probes

392 (Figure 4). Like histochemistry, visualization of the lectin complex is enabled via the use of 393 conjugates such as enzymes, fluorescent dyes, biotin, digoxigenin, colloidal gold and

394 radioactive isotopes. In lectin blotting, the concentrations of lectins used must be at optimal 395 levels to reduce false-positive binding. Although a powerful tool, this technique is however 396 not quite suitable for routine diagnostics. 


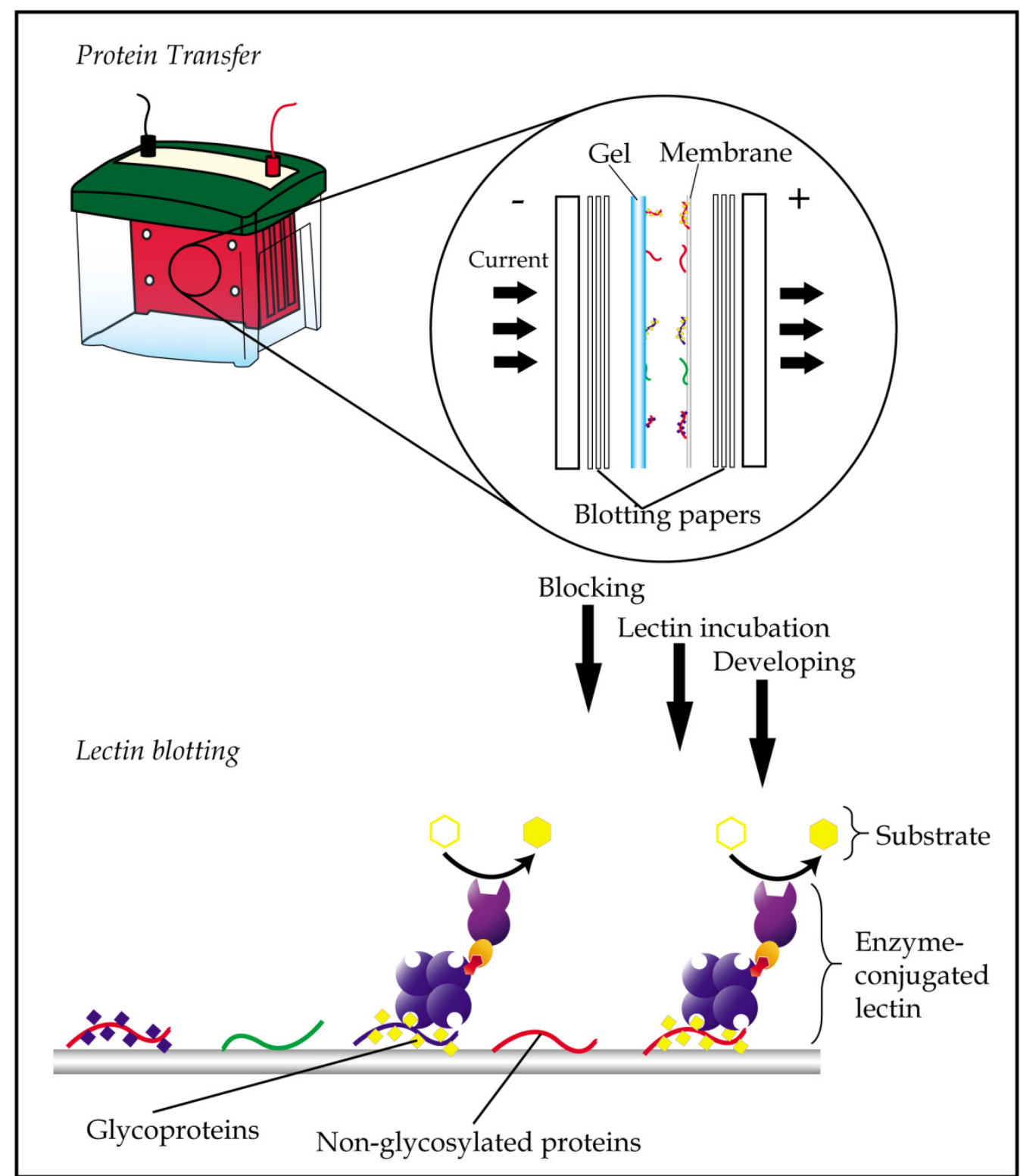

Figure 4 General workflow of lectin blotting. The method initially involves transferring of proteins that are resolved by gel electrophoresis onto a PVDF or nitrocellulose membrane. This is then followed by subjecting the membrane to washing, blocking and incubation with lectins that are conjugated to an enzyme, a fluorescent dye, biotin, digoxigenin, colloidal gold or radioactive isotopes. Comparative blotting of bodily fluids of cancer patients versus those from cancer negative subjects may highlight presence of aberrantly glycosylated and/or expressed glycoproteins. 
In the past, lectin blotting studies have been especially useful in characterization of structures of glycans (Akama and Fukuda, 2006), detection and quantification of $N$ - and $O$ glycosylated proteins (Roth et al., 2012) and detection of altered glycosylation following an abnormality in glycosylation pathways due to disease processes (Kitamura et al., 2003). In cancer biomarker studies, lectin blotting is often used for comprehensive profiling of glycosylated proteins in biofluids. For example, the CGB lectin has been extensively used to demonstrate altered abundances of various $O$-glycosylated proteins in serum and/or urine samples of cancer patients that were resolved by 2-DE and transferred onto nitrocellulose membrane. Cancers that have been investigated using the method include endometrial cancer, cervical cancer (Abdul-Rahman et al., 2007), breast cancer, nasopharyngeal carcinoma, bone cancer (Mohamed et al., 2008), ovarian cancer (Mu et al., 2012) and prostate cancer (Jayapalan et al., 2012; Jayapalan et al., 2013). Similar lectin blotting studies have also been applied on cell lines. Examples are the use of Pinellia pedatisecta agglutinin-based lectin blotting analysis to generate unique glycosylation fingerprints for leukemia and solid tumor cell lines (Li et al., 2014), and the utilization of ConA and CGB lectin to demonstrate altered released of $N$ - and $O$-glycosylated proteins from murine 4T1 mammary carcinoma cell line (Phang et al., 2016).

Another use of lectin blotting is as a means of validation of tumor-specific glycosylation. Based on earlier results that showed elevated levels of mRNA of specific glycosyltransferases in endometroid ovarian cancer tissue relative to normal ovary, Abbott et al. (2010) have selected three different lectins (Phaseolus vulgaris erythroagglutinin, Aleuria aurantia lectin and Datura stramonium lectin) with distinctive affinities for the respective products of the enzymes to validate glycosylation changes of glycoproteins that are expressed 
430 in the ovarian cancer tissues. By extracting intact glycoproteins from the ovarian tissues

431 before isolating the lectin-reactive proteins, the researchers were able to identify a total of 47

432 potential tumor-specific lectin-reactive markers. In another study, Qiu et al. (2008), using

433 biotinylated AAL and SNA lectin-blot detection method, were able to validate the

434 differential $N$-linked glycan patterns that are related to the levels of sialylation and

435 fucosylation of complement C3 in colorectal cancer patients, compared to those with

436 adenoma and normal subjects. Similarly, Park et al., (2012) have validated earlier findings

437 of aberration of fucose residues in haptoglobin $\beta$ chain that is associated with progression of

438 colon cancer by generating comparable results using Lotus tetragonolobus and Aspergillus

439 oryzae lectins as detection probes in lectin blotting experiments.

Lectin array

Lectin array is a technique that was developed for rapid and sensitive analysis of glycans in a high-throughput manner. The technique uses multiple lectins, which are mostly plantderived, that are immobilized onto a solid support at a high spatial density to detect different carbohydrate content of glycoproteins or glycolipids in a single sample (Hu and Wong, 2009; Hirabayashi et al., 2011). Display of the lectins in an array format enables observation of the distinct binding interactions simultaneously, which then provides a unique method for rapid characterization of carbohydrates on glycoconjugates (Figure 5, panel A). A glass slide is the most common material used as solid support for the array application. Lectins are coated on the glass surface either by covalent interaction or physical adsorption. Glass slides are usually pre-treated with chemical derivatives such as $\mathrm{N}$-hydroxy succinimidyl esters (Hsu and Mahal, 2006), epoxides (Kuno et al., 2005), biotin, streptavidin (Angeloni et al., 2005), 


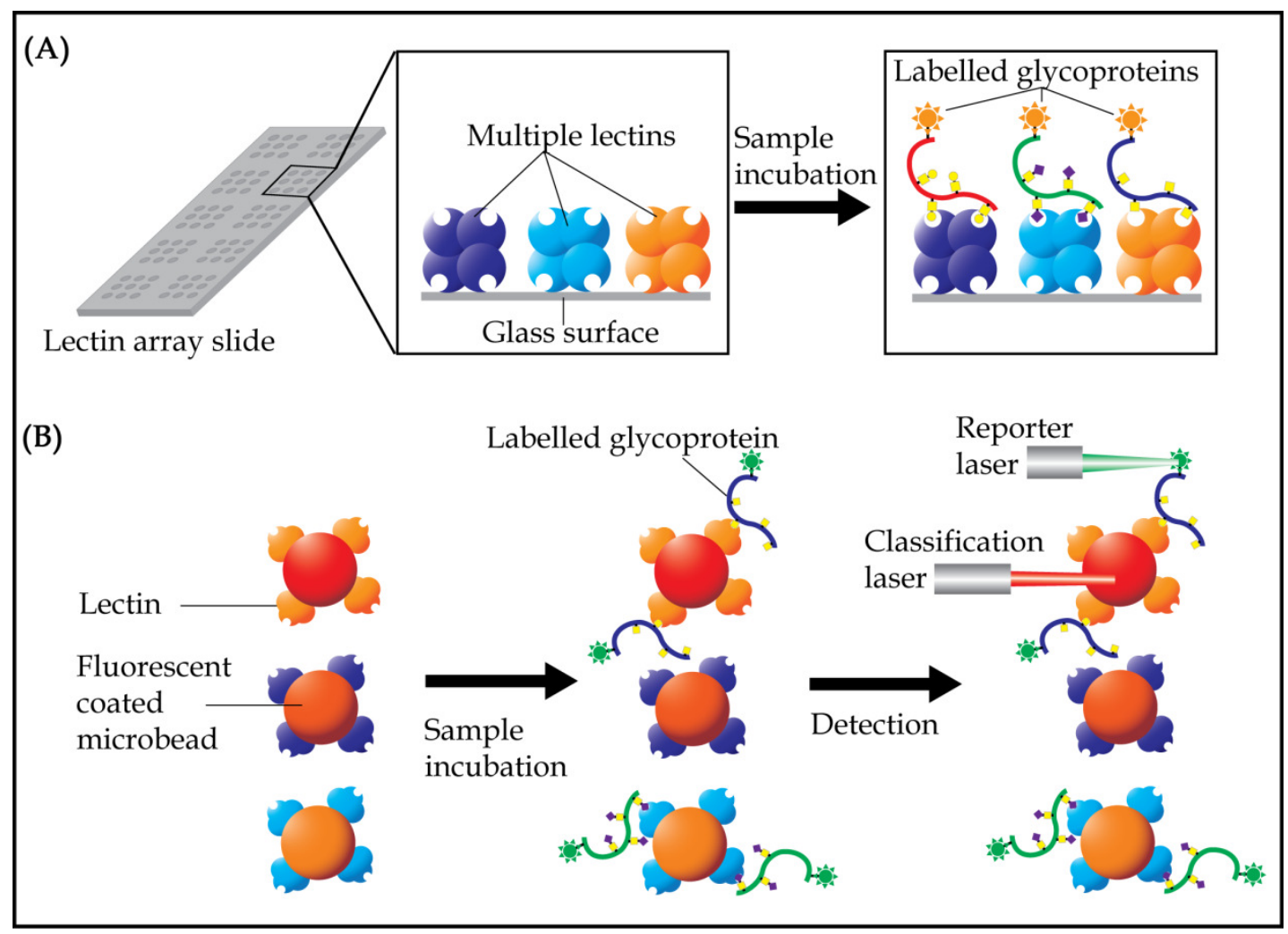

Figure 5 Basic concept of lectin array technology. (A) Multiple lectins are printed onto a slide, which is organized in a grid, single lectin per spot, format. Samples, which are usually pre-labelled with either fluorophore or chromophore, are then allowed to interact with the lectins. Lectin spots, which contain the labelled glycoproteins, will illuminate under an appropriate scanner. (B) In lectin bead array analysis, different fluorescent colored beads, each corresponding to a single lectin, are often used. The conjugated beads are then allowed to interact with samples and the unbound materials being washed out. The beads are then passed through a detector with two laser sources, with the classification laser identifying the specific beads, whilst the reporter laser quantifying presence of the labelled samples. 

cancer, Nakajima et al. (2015) were able to identify 12 lectins that showed increase binding, whilst 11 more lectins demonstrated low binding of glycoproteins in the colorectal cancer tissues compared to normal epithelia. Amongst the lectins, Agaricus bisporus lectin which was selected for further validation by the researchers, showed strong potential to be used as a new predictive biomarker for distant recurrence of curatively resected colorectal cancer. A similar approach performed on tissue extracts of gastric cancer demonstrated high interactions of 13 lectins with tissue glycoproteins, whilst 11 others showed low interaction (Futsukaichi et al., 2015). In both these studies, the altered interaction of lectins only reflected the general presence of glycoproteins that were differently glycosylated without providing any information on the precise glycoproteins that are affected.

In an earlier study, Wu et al. (2012) have used lectin array to screen for altered fucosylated proteins in serum samples of patients with ovarian cancer. Based on the results, the researchers then immobilized the lectins that showed differential interactions and used it as affinity chromatography to isolate serum glycoproteins with aberrant glycan structures and determine their protein identities. This strategy has led to the identification of four serum glycoproteins with altered fucose residues. Recently, a different lectin array strategy was also developed to serve as an analytical technique for determination of differences in glycosylation of proteins that are isolated from serum samples (Sunderic et al., 2016). In this study, the glycan content of serum alpha-2-macrogobulin, which was isolated from serum samples of patients with colorectal cancer, was studied using the lectin array. From a set of 14 fluorescent labelled lectins that were used in the analysis, statistically significant 
490

491

492

493

494

495

496

497

498

499

500

501

502

503

504

505

506

507

508

509

510

511

512

differences between two groups of patients with colorectal cancer and cancer negative individuals were found for five of the lectins. When taken together, the results generally showed that the alpha-2-macrogobulin of patients with colorectal cancer have higher content of $\alpha 2,6$ sialic acid, GlcNAc and mannose residues, and tri-/tetraantennary complex type highmannose $N$-glycans.

Since its inception, the technology of lectin array has been through several modifications to improve detectability of glycoproteins in biological samples. The array may involve prior pre-capturing of a glycoprotein of interest using antibody, and the subsequent detection of glycans using pre-labelled lectins (Kuno et al., 2011; Li et al., 2011). This approach allows detection of the total glycan content of a specific glycoprotein and also reduces the need for prior glycoprotein purification. Lectin array is not limited to glass slide as its solid support. Wang et al. (2014) have used fluorescent dyes coated microbeads, which allows multiplex detection in a single reaction vessel that greatly improves detection sensitivity compared to the standard lectin arrays. More recently, an alternative approach which involves printing of purified samples onto a chip surface has also been reported (Sunderic et al., 2016).

Lectin array analysis can also be performed on magnetic beads (Figure 5, panel B). Known as lectin magnetic bead array, the technique was first introduced as a robust and highthroughput pipeline for glycoproteomics-biomarker discovery in 2010 (Loo et al., 2010). The method is based on use of multiple lectins that are conjugated to magnetic beads to isolate glycan specific proteins. These lectin-conjugated beads are incubated with protein samples, washed and the bound glycoproteins are then eluted in appropriate buffers for subsequent proteomics analysis. By coupling a mass spectrometer to the one-step glycoprotein separation and isolation procedure, profiling of glycan-specific proteins may be 
513 achieved without much loss of proteins. This increases the probability of identification of

514 proteins of lower abundances that have biomarker potentials. Nevertheless, a few

515 methodological concerns need to be carefully considered when using the lectin bead array.

516 These include surface functionality and diameter of the beads, conditions of buffers and

517 duration of trypsin digestion protocols for optimal isolation of lectin-binding proteins. In this

518 technique, understanding of the specificities of lectins is also imperative as most glycosylated

519 proteins are expected to have multiple glycosylation sites for interaction with the lectins.

520 Using a panel of 20 lectins in a magnetic bead array that was coupled to a tandem mass

521 spectrometer, Shah et al. (2015) have demonstrated unique lectin-glycoprotein interactions in

522 serum samples that may be used to distinguish three groups of subjects comprising healthy

523 volunteers, patients with Barrett's esophagus and patients with esophageal adenocarcinoma.

524 Their results demonstrated the possibility of using apolipoprotein B-100 to distinguish

525 healthy volunteers from patients with Barrett's esophagus. The use of Narcissus

526 pseudonarcissus lectin in the assay was able to differentiate differently glycosylated

527 apolipoprotein B-100 in the two groups of subjects. On the other hand, patients with

528 Barrett's esophagus were markedly distinguishable from those with esophageal

529 adenocarcinoma via differences in the glycosylation of AAL-reactive complement

530 component C9, whilst PHA-reactive gelsolin was shown to have potential in differentiating

531 healthy subjects from patients with esophageal adenocarcinoma. 
534 Development and progression of cancer are associated with altered glycosylation and

535 aberrantly expressed glycoproteins. Hence, the use of lectin-based assays and strategies that

536 are discussed in this review article, together with the emergence of proteomics technology,

537 has led to identification of hundreds of putative glycopeptide biomarkers that can be utilized

538 in clinical practice. A summary on the advantages and disadvantages of these lectin-based

539 techniques is shown in Table 4. However, the translation of biomarkers from discovery to

540 clinically approved tests is still much to be desired. This is mainly attributed to the lack of

541 follow-up characterization and validation investigations of the potential biomarkers, which is

542 an absolute requirement to ensure that the discovery phase experiments are not flawed and

543 that detection of the biomarkers is reproducible, specific and sensitive (Diamandis, 2012;

544 Drucker and Krapfenbauer, 2013). A potential glycopeptide biomarker has to be validated

545 using hundreds of specimens to become clinically approved tests. Hence, this is certainly not

546 possible in cases of rare cancers.

548 Table 4 Advantages and disadvantages of lectin-based techniques in cancer biomarker 549 discovery research.

\begin{tabular}{|c|c|c|}
\hline Techniques & Advantages & Disadvantages \\
\hline $\begin{array}{l}\text { Lectin affinity } \\
\text { chromatography }\end{array}$ & $\begin{array}{l}\text { - Does not require purified } \\
\text { glycoproteins or glycans } \\
\text {-Detailed analysis of glycan } \\
\text {-High affinity }\end{array}$ & $\begin{array}{l}\text { - Requires large amounts of } \\
\text { samples } \\
\text { - Time-consuming } \\
\text { - Allows for individual samples } \\
\text { only } \\
\text { - Co-elution of other proteins }\end{array}$ \\
\hline $\begin{array}{l}\text { Enzyme-linked } \\
\text { lectin assay } \\
\text { (ELLA) }\end{array}$ & $\begin{array}{l}\text { - Relatively high-throughput } \\
\text {-Quantitative } \\
\text {-Easy to perform } \\
\text {-Very cost effective } \\
\text { - Requires minute amounts of } \\
\text { samples } \\
\text {-In case of hybrid ELLA, prior }\end{array}$ & $\begin{array}{l}\text { - Glycoproteins that are detected } \\
\text { may not be identifiable unless } \\
\text { it is coupled with further } \\
\text { proteomics analysis or } \\
\text { antibody detection. } \\
\text { - In case of hybrid ELLA, non- } \\
\text { specific direct interaction of }\end{array}$ \\
\hline
\end{tabular}




\begin{tabular}{|c|c|c|}
\hline & $\begin{array}{l}\text { purification of a glycoprotein is } \\
\text { not required }\end{array}$ & $\begin{array}{l}\text { lectin to antibodies may occur } \\
\text { - Require purified glycans or } \\
\text { glycoproteins as standard }\end{array}$ \\
\hline $\begin{array}{l}\text { Lectin } \\
\text { histochemistry }\end{array}$ & $\begin{array}{l}\text {-Simple } \\
\text { - Rapid } \\
\text {-Allows lectin multiplexing } \\
\text { with the use of fluorescent tags }\end{array}$ & $\begin{array}{l}\text { - Requires skills for tissue } \\
\text { preparation } \\
\text { - Requires use of multiple } \\
\text { lectins/antibodies to provide } \\
\text { further confirmation } \\
\text { - Certain fixatives or } \\
\text { components may reduce } \\
\text { sensitivity }\end{array}$ \\
\hline Lectin blotting & $\begin{array}{l}\text {-Visualization of small amounts } \\
\text { of proteins } \\
\text { - Easy to detect } \\
\text { - High specificity and sensitivity } \\
\text { - Reliable and reproducible } \\
\text { - Convenient method of } \\
\text { screening of complex protein } \\
\text { samples }\end{array}$ & $\begin{array}{l}\text { - Choice of membrane may } \\
\text { affect protein binding capacity } \\
\text { and chemical stability }\end{array}$ \\
\hline Lectin array & $\begin{array}{l}\text {-Does not require purified } \\
\text { glycoproteins or glycans } \\
\text { - Rapid } \\
\text { - Highly sensitive } \\
\text { - High-throughput } \\
\text { - Allows multiplexing } \\
\text { - Requires small amounts of } \\
\text { samples }\end{array}$ & $\begin{array}{l}\text { - Requires extensive } \\
\text { optimization } \\
\text {-Possible non-specific } \\
\text { interaction }\end{array}$ \\
\hline
\end{tabular}

In some cases, validation may not be successful with the use of a single cancer biomarker

553 in a single assay. One solution is to explore the simultaneously use of several different

554 biomarkers for development of a highly specific and sensitive assay (Pang et al., 2010).

555 Hence, there is an urgent need to consolidate data on availability of all putative glycopeptide

556 biomarkers that have been unmasked from the discovery phase studies for every different

557 application in every cancer. In addition, new high throughput assays for simultaneous

558 detection of multiple biomarkers are also required. The recent technological advances in 
therefore ought to be explored for simultaneous validation analysis of the different

561 biomarkers in a single experiment.

562

563

564

565

566

567

568

569

570

571

572

573

574

575

576

577

578

579

580

581

582

583

In many other cases, identification of the potential glycopeptide biomarkers using lectinbased strategies may involve complex separation techniques such as 2-DE, which is laborious and expensive for large scale validation studies. 2-DE comes with the advantage of knowing the actual experimental molecular weight of a glycopeptide biomarker, which is not possibly attained from liquid-based separation methods. This is important as many tumor associated glycopeptides are known to be truncated products of native glycoproteins (Pinho and Reis, 2015). For these potential biomarkers, validation experiments would need to involve a different indirect high-throughput technique using both lectin as well as an antibody that is capable of differentiating truncated glycopeptides from their native glycoprotein structures. However, such antibodies are usually not available commercially, and generating them is time consuming, costly and involves substantial laboratory work.

\section{References}

\section{Abbott KL, Lim J-M, Wells L, Benigno BB, McDonald JF, and Pierce M. 2010.}

Identification of candidate biomarkers with cancer-specific glycosylation in the tissue and serum of endometrioid ovarian cancer patients by glycoproteomic analysis. Proteomics 10(3):470-481. DOI:10.1002/pmic.200900537.

\section{Abdul Rahman M, Anuar Karsani S, Othman I, Shafinaz Abdul Rahman P, and Haji}

Hashim O. 2002. Galactose binding lectin from the seeds of champedak (Artocarpus integer): sequences of its subunits and interactions with human serum $O$-glycosylated glycoproteins, Biochemical Biophysical Research Communications 295:1007-1013. https://doi.org/10.1016/S0006-291X(02)00795-7. 
584

585

586

587

588

589

590

591

592

593

594

595

596

597

598

599

600

601

602

603

604

605

606

607

608

609

610

611

Abdul-Rahman PS, Lim BK, and Hashim OH. 2007. Expression of high-abundance proteins in sera of patients with endometrial and cervical cancers: Analysis using 2-DE with silver staining and lectin detection methods. Electrophoresis 28(12):1989-1996. DOI:10.1002/elps.200600629.

Ahmad E, Kamranur Rahman S, Masood Khan J, Varshney A, and Hasan Khan R. 2009. Phytolacca americana lectin (Pa-2; pokeweed mitogen): an intrinsically unordered protein and its conversion into partial order at low pH. Bioscience Report 30(2):125-134. DOI:10.1042/BSR20090035.

Akama TO, and Fukuda MN. 2006. $N$-Glycan structure analysis using lectins and an alphamannosidase activity assay. Methods in Enzymology 416:304-314. DOI:10.1016/s00766879(06)16020-6.

Angeloni S, Ridet JL, Kusy N, Gao H, Crevoisier F, Guinchard S, Kochhar S, Sigrist H, and Sprenger N. 2005. Glycoprofiling with micro-arrays of glycoconjugates and lectins. Glycobiology 15(1):31-41. DOI:10.1093/glycob/cwh143.

Barry MJ. 2001. Prostate specific antigen testing for early diagnosis of prostate cancer. The New England Journal of Medicine 344:1373-1377. DOI:10.1056/NEJM200105033441806.

Batterbury M, Tebbs CA, Rhodes JM, and Grierson I. 2002. Agaricus bisporus (edible mushroom lectin) inhibits ocular fibroblast proliferation and collagen lattice contraction. Experimental Eye Research 74:361-370. DOI:10.1006/exer.2001.1133.

Bellei E, Bergamini S, Monari E, Fantoni LI, Cuoghi A, Ozben T, and Tomasi A. 2011. High-abundance proteins depletion for serum proteomic analysis: concomitant removal of non-targeted proteins. Amino Acids 40:145-156. DOI:10.1007/s00726-010-0628-X.

Benedito VA, Torres-Jerez I, Murray JD, Andriankaja A, Allen S, Kakar K, Wandrey M, Verdier J, Zuber H, Ott T, Moreau S, Niebel A, Frickey T, Weiller G, He J, Dai X, Zhao PX, Tang Y, and Udvardi MK. 2008. A gene expression atlas of the model legume Medicago truncatula. The Plant Journal 55(3):504-513. DOI:10.1111/j.1365313X.2008.03519.x. 
612

613

614

615

616

617

618

619

620

621

622

623

624

625

626

627

628

629

630

631

632

633

634

635

636

637

Biomarkers Definition Working Group. 2001. Biomarkers and surrogate endpoints:

Preferred definitions and conceptual framework. Clinical Pharmacology \& Therapeutics 69(3):89-95. DOI:10.1067/mcp.2001.113989.

Boyd WC, and Shapleigh E. 1954. Antigenic relations of blood group antigens as suggested by tests with lectins. The Journal of Immunology 73(4):226-231.

Brooks SA, and Hall DM. (2012). Lectin histochemistry to detect altered glycosylation in cells and tissues. Methods in Molecular Biology 878:31-50. DOI:10.1007/978-1-61779854-2_2.

\section{Brustein VP, Souza-Araujo FV, Vaz AF, Araujo RV, Paiva PM, Coelho LC, Carneiro-} Leao AM, Teixeira JA, Carneiro-da-Cunha MG, and Correia MT. 2012. A novel antimicrobial lectin from Eugenia malaccensis that stimulates cutaneous healing in mice model. Inflammopharmacology 20:315-322. DOI:10.1007/s10787-011-0113-5.

Chacko BK, and Appukuttan PS. 2001. Peanut (Arachis hypogaea) lectin recognizes alpha-linked galactose, but not $N$-acetyl lactosamine in $N$-linked oligosaccharide terminals. International Journal of Biological Macromolecules 28(5):365-371.

Chan YS, Yu H, Xia L, and Ng TB. 2015. Lectin from green speckled lentil seeds (Lens culinaris) triggered apoptosis in nasopharyngeal carcinoma cell lines. Chinese Medicine 10: 25. DOI:10.1186/s13020-015-0057-6.

Charles PT, Goldman ER, Rangasammy JG, Schauer CL, Chen MS, and Taitt CR. 2004. Fabrication and characterization of $3 \mathrm{D}$ hydrogel microarrays to measure antigenicity and antibody functionality for biosensor applications. Biosensors and Bioelectronics 20(4):753-764. DOI:10.1016/j.bios.2004.04.007.

Chen Y, Peumans WJ, Hause B, Bras J, Kumar M, Proost P, Barre A, Rouge P, and Van Damme EJ. 2002. Jasmonic acid methyl ester induces the synthesis of a cytoplasmic/nuclear chito-oligosaccharide binding lectin in tobacco leaves. FASEB Journal 16:905-907. DOI:10.1096/fj.01-0598fje. 
638

639

640

641

642

643

644

645

646

647

648

649

650

651

652

653

654

655

656

657

658

659

660

661

662

663

664

665

Ching CK, and Rhodes JM. 1989. Enzyme-linked PNA lectin binding assay compared with CA19-9 and CEA radioimmunoassay as a diagnostic blood test for pancreatic cancer. British Journal of Cancer 59(6):949-953.

\section{Coelho LCBB, dos Santos Silva PM, de Menezes Lima VL, Pontual EV, Paiva PMG,} Napoleão TH,1 and dos Santos Correia MT (2017). Lectins, interconnecting proteins with biotechnological/pharmacological and therapeutic applications. Evidence-Based Complementary and Alternative Medicine. 2017:1594074, https://doi.org/10.1155/2017/1594074.

Coriolano MC, de Melo CM, Silva Fde O, Schirato GV, Porto CS, dos Santos PJ, Correia MT, Porto AL, Carneiro-Leao AM, and Coelho LC. 2014. Parkia pendula seed lectin: potential use to treat cutaneous wounds in healthy and immunocompromised mice. Applied Biochemistry and Biotechnology 172:2682-2693. DOI:10.1007/s12010013-0692-2.

De Hoff PL, Brill LM, and Hirsch AM. 2009. Plant lectins: the ties that bind in root symbiosis and plant defense. Molecular Genetics and Genomics 282(1):1-15. DOI:10.1007/s00438-009-0460-8.

Diamandis EP. 2012. The failure of protein cancer biomarkers to reach the clinic: why, and what can be done to address the problem? BMC Medicine 10:87. DOI:10.1186/17417015-10-87.

Dias RD, Machado LD, Migliolo L, and Franco OL. 2015. Insights into animal and plant lectins with antimicrobial activities. Molecules 20(1):519-541. DOI:10.3390/molecules20010519.

Ditamo Y, Rupil LL, Sendra VG, Nores GA, Roth GA, and Irazoqui FJ. 2016. In vivo immunomodulatory effect of the lectin from edible mushroom Agaricus bisporus. Food and Function 7:262-269. DOI:10.1039/c5fo00360a.

\section{Dos-Santos PB, Zanetti JS, Vieira-De-Mello GS, Rego MBM, Ribeiro-Silva AA, and} Beltrao EIC. (2014). Lectin histochemistry reveals SNA as a prognostic carbohydratedependent probe for invasive ductal carcinoma of the breast: a clinicopathological and 

immunohistochemical auxiliary tool. International Journal of Clinical and Experimental Pathology 7(5):2337-2349.

668

669

670

671

672

673

674

675

676

677

678

679

680

681

682

683

684

685

686

687

688

689

690

691

692

693

Drucker E, and Krapfenbauer K. 2013. Pitfalls and limitations in translation from biomarker discovery to clinical utility in predictive and personalised medicine. The EPMA Journal 4(1):7. DOI:10.1186/1878-5085-4-7.

Dwek MV, Jenks A, and Leathem AJ. 2010. A sensitive assay to measure biomarker glycosylation demonstrates increased fucosylation of prostate specific antigen (PSA) in patients with prostate cancer compared with benign prostatic hyperplasia. Clinica Chimica Acta 411:1935-1839. DOI:10.1016/j.cca.2010.08.009.

\section{Futsukaichi T, Etoh T, Nakajima K, Daa T, Shiroshita H, Shiraishi N, Kitano S, and} Inomata M. 2015. Decreased expression of Bauhinia purpurea lectin is a predictor of gastric cancer recurrence. Surgery Today 45:1299-1306. DOI:10.1007/s00595-015-11271.

Füzéry AK, Levin J, Chan MM, and Chan DW. 2013. Translation of proteomic biomarkers into FDA approved cancer diagnostics: issues and challenges. Clinical Proteomics 10:1-14. DOI:10.1186/1559-0275-10-13.

Gabrielsen M, Abdul-Rahman PS, Othman S, Hashim OH, and Cogdell RJ. 2014. Structures and binding specificity of galactose- and mannose-binding lectins from champedak: Differences from jackfruit lectins. Acta Crystallographica Section F, Structural Biology Communications 70:709-716. DOI:10.1107/S2053230X14008966.

Geisler C, and Jarvis DL. 2011. Letter to the Glyco-Forum: Effective glycoanalysis with Maackia amurensis lectins requires a clear understanding of their binding specificities. Glycobiology 21:988-993. DOI:10.1093/glycob/cwr080.

Hagerbaumer P, Vieth M, Anders M, and Schumacher U. (2015). Lectin histochemistry shows WGA, PHA-L and HPA binding increases during progression of human colorectal cancer. Anticancer Research 35(10):5333-5339.

Harley SM, and Beevers H. 1986. Lectins in Castor Bean Seedlings. Plant Physiol 80,16.Hage DS, Anguizola JA, Bi C, Li R, Matsuda R, Papastavros E, Pfaunmiller E, 
694

695

696

697

698

699

700

701

702

703

704

705

706

707

708

Vargas J, and Zheng X. 2012. Pharmaceutical and biomedical applications of affinity chromatography: Recent trends and developments. Journal of Pharmaceutical and Biomedical Analysis. 69:93-105. DOI:10.1016/j.jpba.2012.01.004.

Hashim OH, Ng CL, Gendeh S, and Nik Jaafar MI. 1991. IgA binding lectins isolated from distinct Artocarpus species demonstrate differential specificity. Molecular Immunology 28:393-398.

Hassan MAA, Rouf R, Tiralongo E, May TW, and Tiralongo J. 2015. Mushroom lectins: Specificity, structure and bioactivity relevant to human disease. International Journal of Molecular Sciences 16:7802-7838. DOI:10.3390/ijms16047802.

Heim C, Hertzberg H, Butschi A, Bleuler-Martinez S, Aebi M, Deplazes P, Kunzler M, and Stefanic S. 2015. Inhibition of Haemonchus contortus larval development by fungal lectins. Parasites and Vectors 8:425. DOI:10.1186/s13071-015-1032-x.

Henry NL, and Hayes DF. 2012. Cancer biomarkers. Molecular Oncology 6(2):140-146. https://doi.org/10.1016/j.molonc.2012.01.010.

Hirabayashi J, Kuno A, and Tateno H. 2011. Lectin-based structural glycomics: a practical approach to complex glycans. Electrophoresis 32(10):1118-1128. DOI:10.1002/elps.201000650.

Holthofer H, Virtanen I, Kariniemi AL, Hormia M, Linder E, and Miettinen A. 1982. Ulex europaeus I lectin as a marker for vascular endothelium in human tissues. Laboratory Investigation 47(1):60-66.

Hong P, Koza S, and Bouvier ESP. 2012. Size-exclusion chromatography for the analysis of protein biotherapeutics and their aggregates. Journal of Liquid Chromatography \& Related Technologies 35(20):2923-2950. DOI:10.1080/10826076.2012.743724.

Howard IK, Sage HJ, Stein MD, Young NM, Leon MA, and Dyckes DF. 1971. Studies on a phytohemagglutinin from the lentil. II. Multiple forms of Lens culinaris hemagglutinin. Journal of Biological Chemistry 246(6): 1590-1595.

Hsu KL, and Mahal LK. 2006. A lectin microarray approach for the rapid analysis of bacterial glycans. Nature Protocols 1(2):543-549. DOI:10.1038/nprot.2006.76. 
722

723

724

725

726

727

728

729

730

731

732

733

734

735

736

737

738

739

740

741

742

743

744

745

746

747

748

Hu S, and Wong DT. 2009. Lectin microarray. Proteomics Clinical Applications 3(2):148154. DOI:10.1002/prca.200800153.

\section{Indramanee S, Silsirivanit A, Pairojkul C, Wongkham C, and Wongkham S, 2012.} Aberrant glycosylation in cholangiocarcinoma demonstrated by lectin-histochemistry. Asian Pacific Journal of Cancer Prevention, 13:119-124.

Jagtap UB, and Bapat VA. 2010. Artocarpus: a review of its traditional uses, phytochemistry and pharmacology. Journal of Ethnopharmacology 129(2):142-166. DOI:10.1016/j.jep.2010.03.031.

Jayapalan JJ, Ng KL, Razack AHA, and Hashim OH. 2012. Identification of potential complementary serum biomarkers to differentiate prostate cancer from benign prostatic hyperplasia using gel- and lectin-based proteomics analyses. Electrophoresis 33(12):1855-1862. DOI:10.1002/elps.201100608.

Jayapalan JJ, Ng KL, Shuib AS, Razack AH, and Hashim OH. 2013. Urine of patients with early prostate cancer contains lower levels of light chain fragments of inter-alphatrypsin inhibitor and saposin B but increased expression of an inter-alpha-trypsin inhibitor heavy chain 4 fragment. Electrophoresis 34(11):1663-1669. DOI:10.1002/elps.201200583.

Jebali J, Fakhfekh E, Morgen M, Srairi-Abid N, Majdoub H, Gargouri A, El Ayeb M, Luis J, Marrakchi N, and Sarray S. 2014. Lebecin, a new C-type lectin like protein from Macrovipera lebetina venom with anti-tumor activity against the breast cancer cell line MDA-MB231. Toxicon 86:16-27. DOI:10.1016/j.toxicon.2014.04.010.

Jin Y, Kim SC, Kim HJ, Ju W, Kim YH, and Kim HJ. 2016. A lectin-based diagnostic system using circulating antibodies to detect cervical intraepithelial neoplasia and cervical cancer. Glycobiology, 26(1):100-107. DOI:10.1093/glycob/cwv075.

Kabir S. 1995. The isolation and characterisation of jacalin [Artocarpus heterophyllus (jackfruit) lectin] based on its charge properties. The International Journal of Biochemistry and Cell Biology 27(2):147-156. 
Kaku H, Van Damme EJ, Peumans WJ, and Goldstein IJ. 1990. Carbohydrate-binding specificity of the daffodil (Narcissus pseudonarcissus) and amaryllis (Hippeastrum hybr.) bulb lectins. Archives of Biochemistry and Biophysics 279(2):298-304.

\section{Kaneda Y, Whittier RF, Yamanaka H, Carredano E, Gotoh M, Sota H, Hasegawa Y, and Shinohara Y. 2002. The high specificities of Phaseolus vulgaris erythro- and leukoagglutinating lectins for bisecting GlcNAc or $\beta 1-6$-linked branch structures, respectively, are attributable to loop B. Journal of Biological Chemistry 277:16928- 16935. DOI:10.1074/jbc.M112382200.}

Kim HJ, Kim SC, Ju W, Kim YH, Yin SY, and Kim HJ. 2014. Aberrant sialylation and fucosylation of intracellular proteins in cervical tissue are critical markers of cervical carcinogenesis. Oncology Reports 31(3):1417-1422. DOI:10.3892/or.2013.2938.

Kim HJ, Lee SJ, and Kim HJ. 2008. Antibody-based enzyme-linked lectin assay (ABELLA) for the sialylated recombinant human erythropoietin present in culture supernatant. Journal of Pharmaceutical and Biomedical Analysis 48(3):716-721. DOI:10.1016/j.jpba.2008.07.004.

Kino M, Yamaguchi K, Umekawa H, and Funatsu G. 1995. Purification and characterization of three mitogenic lectins from the roots of pokeweed (Phytolacca americana). Bioscience, Biotechnology and Biochemistry 59(4):683-688.

\section{Kitamura N, Guo S, Sato T, Hiraizumi S, Taka J, Ikekita M, Sawada S, Fujisawa H,} and Furukawa K. 2003. Prognostic significance of reduced expression of beta- $N$ acetylgalactosaminylated $N$-linked oligosaccharides in human breast cancer. International Journal of Cancer 105:533-541. DOI:10.1002/ijc.11115.

Klafke GB, Moreira GM, Monte LG, Pereira JL, Brandolt TM, Xavier MO, SantiGadelha T, Dellagostin OA, and Pinto Lda S. 2013. Assessment of plant lectin antifungal potential against yeasts of major importance in medical mycology. Mycopathologia 175:147-151. DOI:10.1007/s11046-012-9596-x.

Konami Y, Yamamoto K, Osawa T, and Irimura T. 1994. Strong affinity of Maackia amurensis hemagglutinin (MAH) for sialic acid-containing Ser/Thr-linked carbohydrate 
chains of $N$-terminal octapeptides from human glycophorin A. FEBS letters 342:334-338. http://dx.doi.org/10.1016/0014-5793(94)80527-X.

Kuhlmann WD, and Peschke P. (1984). Comparative study of procedures for histological detection of lectin binding by use of Griffonia simplicifolia agglutinin I and gastrointestinal mucosa of the rat. Histochemistry 81(3):265-272. DOI:10.1007/BF00495637.

\section{Kuno A, Ikehara Y, Tanaka Y, Angata T, Unno S, Sogabe M, Ozaki H, Ito K,} Hirabayashi J, Mizokami M, and Narimatsu H. 2011. Multilectin assay for detecting fibrosis-specific glyco-alteration by means of lectin microarray. Clinical Chemistry 57(1):48-56. DOI:10.1373/clinchem.2010.151340.

\section{Kuno A, Uchiyama N, Koseki-Kuno S, Ebe Y, Takashima S, Yamada M, and} Hirabayashi J. 2005. Evanescent-field fluorescence-assisted lectin microarray: a new strategy for glycan profiling. Nature Methods 2(11):851-856. DOI:10.1038/nmeth803.

Kuzmanov U, Kosanam H, and Diamandis EP. 2013. The sweet and sour of serological glycoprotein tumor biomarker quantification. BMC Medicine 11:31. DOI:10.1186/17417015-11-31.

\section{Lee CS, Muthusamy A, Abdul-Rahman PS, Bhavanandan VP, and Hashim OH. 2013.} An improved lectin-based method for the detection of mucin-type $O$-glycans in biological samples. Analyst 138(12):3522-3529. DOI:10.1039/c3an36258b.

\section{Lee CS, Taib NA, Ashrafzadeh A, Fadzli F, Harun F, Rahmat K, Hoong SM, Abdul-} Rahman PS, and Hashim OH. 2016. Unmasking heavily $O$-glycosylated serum proteins using perchloric acid: identification of serum proteoglycan 4 and protease $\mathrm{C} 1$ inhibitor as molecular indicators for screening of breast cancer. PLoS One 11(2):e0149551. DOI:10.1371/journal.pone.0149551.

Leong KH, Chung LY, Noordin MI, Onuki Y, Morishita M, and Takayama K. 2011. Lectin-functionalized carboxymethylated kappa-carrageenan microparticles for oral insulin delivery. Carbohydrate Polymers 86:555-565. 
805

806

807

808

809

810

811

812

813

814

815

816

817

818

819

820

821

822

823

824

825

826

827

828

829

830

831

Lescar J, Loris R, Mitchell E, Gautier C, Chazalet V, Cox V, Wyns L, Pérez S, Breton C, and Imberty A. 2002. Isolectins I-A and I-B of Griffonia (Bandeiraea) simplicifolia: Crystal structure of metal-free GS I-B4 and molecular basis for metal binding and monosaccharide specificity. Journal of Biological Chemistry 277:6608-6614. DOI:10.1074/jbc.M109867200.

Li N, Dong G, Wang S, Zhu S, Shen Y, and Li G. 2014. Pinellia pedatisecta agglutininbased lectin blot analysis distinguishes between glycosylation patterns in various cancer cell lines. Oncology Letters 8(2):837-840. DOI:10.3892/ol.2014.2201.

Li Y, Tao SC, Bova GS, Liu AY, Chan DW, Zhu H, and Zhang H. 2011. Detection and verification of glycosylation patterns of glycoproteins from clinical specimens using lectin microarrays and lectin-based immunosorbent assays. Analytical Chemistry 83(22):8509-8516. DOI:10.1021/ac201452f.

Liang Y, Ma T, Thakur A, Yu H, Gao L, Shi P, Li X, Ren H, Jia L, Zhang S, Li Z, and Chen M. 2015. Differentially expressed glycosylated patterns of alpha-1-antitrypsin as serum biomarkers for the diagnosis of lung cancer. Glycobiology 25(3):331-340. DOI:10.1093/glycob/cwu115.

Lim SB, Chua CT, and Hashim OH. 1997. Isolation of a mannose-binding and IgE- and IgM-reactive lectin from the seeds of Artocarpus integer. Journal of Immunological Methods 209(2):177-186.

Lin D, Alborn WE, Slebos RJC, and Liebler DC (2013). Comparison of protein immunoprecipitation-multiple reaction monitoring with ELISA for assay of biomarker candidates in plasma. Journal of Proteome Research 12(12):5996-6003. DOI:10.1021/pr400877e.

Lis H, and Sharon N. 1986. Lectins as molecules and as tools. Annual Review of Biochemistry 55:35-67. DOI:10.1146/annurev.bi.55.070186.000343.

Llop E, Ferrer-Batalle M, Barrabes S, Guerrero PE, Ramirez M, Saldova R, Rudd PM, Aleixandre RN, Comet J, de Llorens R, and Peracaula R. 2016. Improvement of 
832

833

834

835

836

837

838

839

840

841

842

843

844

845

846

847

848

849

850

851

852

853

854

855

856

857

858

prostate cancer diagnosis by detecting PSA glycosylation-specific changes. Theranostics 6(8):1190-1204. DOI:10.7150/thno.15226.

Loo D, Jones A, and Hill MM. 2010. Lectin magnetic bead array for biomarker discovery. Journal of Proteome Research 9(10):5496-5500. DOI:10.1021/pr100472z.

Lopez S, Codina C, Bastida J, Viladomat F, Davidson E, and Stewart D. 2002. Biodiversity of mannose-specific lectins within Narcissus species. Journal of Agricultural and Food Chemistry 50(9):2507-2513.

Macedo MLR, Oliveira CFR, and Oliveira CT. 2015. Insecticidal activity of plant lectins and potential application in crop protection. Molecules 20(2):2014-2033. DOI:10.3390/molecules20022014.

Lusvarghi S, and Bewley CA. 2016. Griffithsin: an antiviral lectin with outstanding therapeutic potential. Viruses 8:296. DOI:10.3390/v8100296.

\section{Matsumura K, Higashida K, Ishida H, Hata Y, Yamamoto K, Shigeta M, Mizuno-} Horikawa Y, Wang X, Miyoshi E, Gu J, and Taniguchi N. 2007. Carbohydrate binding specificity of a fucose-specific lectin from Aspergillus oryzae: A novel probe for core fucose. Journal of Biological Chemistry 282:15700-15708.

DOI:10.1074/jbc.M701195200.

McCoy JP, Jr., Varani J, and Goldstein IJ. 1983. Enzyme-linked lectin assay (ELLA): use of alkaline phosphatase-conjugated Griffonia simplicifolia $\mathrm{B} 4$ isolectin for the detection of alpha-D-galactopyranosyl end groups. Analytical Biochemistry 130(2):437-444.

Miyamoto S, Ruhaak LR, Stroble C, Salemi MR, Phinney B, Lebrilla CB, and

Leiserowitz GS. 2016. Glycoproteomic analysis of malignant ovarian cancer ascites fluid identifies unusual glycopeptides. Journal of Proteome Research 15(9):3358-3376. DOI:10.1021/acs.jproteome.6b00548.

Mohamed E, Abdul-Rahman PS, Doustjalali SR, Chen Y, Lim BK, Omar SZ, Bustam AZ, Singh VA, Mohd-Taib N, Yip CH, and Hashim OH. 2008. Lectin-based electrophoretic analysis of the expression of the $35 \mathrm{kDa}$ inter-alpha-trypsin inhibitor 
heavy chain $\mathrm{H} 4$ fragment in sera of patients with five different malignancies. Electrophoresis 29(12):2645-2650. DOI:10.1002/elps.200700828.

Monteiro JT, and Lepenies B. 2017. Myeloid C-type lectin receptors in viral recognition and antiviral immunity. Viruses 9:59.

863

864

865

866

867

868

869

870

871

872

873

874

875

876

877

878

879

880

881

882

883

884

885

886

Movafagh A, Ghanati K, Amani D, Mahdavi SM, Hashemi M, Abdolahi DZ, Darvish H, Gholami M, HaghNejad L, Mosammami S, Safari S, Darehgazani R, Rahimi M, Naini NS, Motlagh MG, and Zamani M. 2013. The structure biology and application of phytohemagglutinin (PHA) in phytomedicine: With special up-to-date references to lectins. Journal of Paramedical Sciences 4. http://journals.sbmu.ac.ir/jps/article/view/4037.

Mu AK-W, Lim B-K, Hashim OH, and Shuib AS. 2012. Detection of differential levels of proteins in the urine of patients with endometrial cancer: Analysis using two-dimensional gel electrophoresis and $O$-glycan binding lectin. International Journal of Molecular Sciences 13(8):9489-9501. DOI:10.3390/ijms13089489.

Nagata Y, and Burger MM. 1972. Wheat germ agglutinin: Isolation and Crystallization. The Journal of Biological Chemistry 247:2248-2250.

Nakajima K, Inomata M, Iha H, Hiratsuka T, Etoh T, Shiraishi N, Kashima K, and Kitano S. 2015. Establishment of new predictive markers for distant recurrence of colorectal cancer using lectin microarray analysis. Cancer Medicine 4(2):293-302. DOI:10.1002/cam4.342.

Nakamura-Tsuruta S, Kominami J, Kuno A, and Hirabayashi J. 2006. Evidence that Agaricus bisporus agglutinin (ABA) has dual sugar-binding specificity. Biochemical and Biophysical Research Communications 347(1):215-220.

DOI:10.1016/j.bbrc.2006.06.073.

Neutsch L, Wirth EM, Spijker S, Pichl C, Kahlig H, Gabor F, and Wirth M. 2013. Synergistic targeting/prodrug strategies for intravesical drug delivery-lectin-modified PLGA microparticles enhance cytotoxicity of stearoyl gemcitabine by contact-dependent transfer. Journal of Controlled Release 169:62-72. DOI:10.1016/j.jconrel.2013.04.004. 
887 888

889

890

891

892

893

894

895

896

897

898

899

900

901

902

903

904

905

906

907

908

909

910

911

912

913

Norum LF, Erikstein B, and Nustad K. 2001. Elevated CA125 in breast cancer - A sign of advanced disease. Tumour Biology 22(4):223-228. DOI:50620.

Pang WW, Abdul-Rahman PS, Wan-Ibrahim WI, and Hashim OH. 2010. Can the acutephase reactant proteins be used as cancer biomarkers? The International Journal of Biological Markers 25(1):1-11.

Parasuraman P, Murugan V, Selvin JF, Gromiha MM, Fukui K, and Veluraja K. 2014. Insights into the binding specificity of wild type and mutated wheat germ agglutinin towards Neu5Acalpha(2-3)Gal: a study by in silico mutations and molecular dynamics simulations. Journal of Molecular Recognition 27:482-492. DOI:10.1002/jmr.2369.

Park SY, Lee SH, Kawasaki N, Itoh S, Kang K, Hee Ryu S, Hashii N, Kim JM, Kim JY, and Hoe Kim J. 2012. Alpha1-3/4 fucosylation at Asn 241 of beta-haptoglobin is a novel marker for colon cancer: a combinatorial approach for development of glycan biomarkers. International Journal of Cancer 130(10):2366-2376. DOI:10.1002/ijc.26288.

Percin I, Yavuz H, Aksoz E, and Denizli A. 2012. Mannose-specific lectin isolation from Canavalia ensiformis seeds by PHEMA-based cryogel. Biotechnology Progress 28(3):756-761. DOI:10.1002/btpr.1552.

Pereira MEA, and Kabat EA. 1974. Specificity of purified hemagglutinin (lectin) from Lotus tetragonolobus. Biochemistry 13:3184-3192. DOI:10.1021/bi00712a029.

Peumans WJ, van Damme JM, Barre A, Rougé P. 2001. Classification of Plant Lectins in families of structurally and evolutionary related proteins. In: The molecular immunology of complex carbohydrates -2. Boston, MA: Springer US. p. 27-54.

Phang W-M, Tan A-A, Gopinath SCB, Hashim OH, Kiew LV, and Chen Y. 2016. Secretion of $N$ - and $O$-linked glycoproteins from 4T1 murine mammary carcinoma cells. International Journal of Medical Sciences 13(5):330-339. DOI:10.7150/ijms. 14341.

Pihíková D, Kasák P, and Tkac J, 2015. Glycoprofiling of cancer biomarkers: Label-free electrochemical lectin-based biosensors. Open Chemistry 13(1):636-655.

DOI:10.1515/chem-2015-0082. 
914

915

916

917

918

919

920

921

922

923

924

925

926

927

928

929

930

931

932

933

934

935

936

937

938

939

940

941

Pinho SS, and Reis CA. 2015. Glycosylation in cancer: mechanisms and clinical implications. Nature Reviews Cancer 15(9):540-55. DOI:10.1038/nrc3982.

PolaskovaV, Kapur A, Khan A, Molloy MP, and Baker MS. 2010. High-abundance protein depletion: Comparison of methods for human plasma biomarker discovery. Electrophoresis 31(3):471-482. DOI:10.1002/elps.200900286.

Prieto DA, Johann DJ, Wei B-R, Ye X, Chan KC, Nissley DV, Simpson RM, Citrin DE, Mackall CL, Linehan WM, and Blonder J. 2014. Mass spectrometry in cancer biomarker research: a case for immunodepletion of abundant blood-derived proteins from clinical tissue specimens. Biomarkers in Medicine 8(2):269-286. DOI:10.2217/bmm.13.101.

Qi YJ, Ward DG, Pang C, Wang QM, Wei W, Ma J, Zhang J, Lou Q, Shimwell NJ, Martin A, Wong N, Chao WX, Wang M, Ma YF, and Johnson PJ. 2014. Proteomic profiling of $N$-linked glycoproteins identifies ConA-binding procathepsin $\mathrm{D}$ as a novel serum biomarker for hepatocellular carcinoma. Proteomics 14:186-195. DOI:10.1002/pmic.201300226.

Qiu Y, Patwa TH, Xu L, Shedden K, Misek DE, Tuck M, Jin G, Ruffin MT, Turgeon DK, Synal S, Bresalier R, Marcon N, Brenner DE, and Lubman DM. 2008. Plasma glycoprotein profiling for colorectal cancer biomarker identification by lectin glycoarray and lectin blot. Journal of Proteome Research 7(4):1693-1703. DOI:10.1021/pr700706s.

Quiroga AV, Barrio DA, and Añón MC. 2015. Amaranth lectin presents potential antitumor properties. LWT - Food Science and Technology 60:478-485. DOI:10.1016/j.1wt.2014.07.035.

Raj Bharath R, and Krishnan V. 2016. Role of plant based lectins in identifying rare bombay blood group. Pharmacognosy Journal 8. DOI:10.5530/pj.2016.1.15.

Reddi AL, Sankaranarayanan K, Arulraj HS, Devaraj N, and Devaraj H. 2000. Enzyme-linked PNA lectin-binding assay of serum T-antigen in patients with SCC of the uterine cervix. Cancer Letters 149:207-211. https://doi.org/10.1016/S03043835(99)00363-8. 
942

943

944

945

946

947

948

949

950

951

952

953

954

955

956

957

958

959

960

961

962

963

964

965

966

967

968

969

Redondo MJ, and Alvarez-Pellitero P. 2010. The effect of lectins on the attachment and invasion of Enteromyxum scophthalmi (Myxozoa) in turbot (Psetta maxima L.) intestinal epithelium in vitro. Experimental Parasitology 126:577-581.

DOI:10.1016/j.exppara.2010.06.008.

\section{Regente M, Taveira GB, Pinedo M, Elizalde MM, Ticchi AJ, Diz MS, Carvalho AO, de}

la Canal L, and Gomes VM. 2014. A sunflower lectin with antifungal properties and putative medical mycology applications. Current Microbiology 69:88-95.

DOI:10.1007/s00284-014-0558-z.

\section{Rodriguez-Pineiro AM, Ayude D, Rodriguez-Berrocal FJ, and Paez de la Cadena M.} 2004. Concanavalin A chromatography coupled to two-dimensional gel electrophoresis improves protein expression studies of the serum proteome. Journal of Chromatography B. Analytical Technologies in the Biomedical and Life Sciences 803(2):337-343. DOI:10.1016/j.jchromb.2004.01.019.

Roth Z, Yehezkel G, and Khalaila I. 2012. Identification and quantification of protein glycosylation. International Journal of Carbohydrate Chemistry 2012:640923. DOI:10.1155/2012/640923.

Roth J. (2011). Lectins for histochemical demonstration of glycans. Histochemistry and Cell Biology 136(2):117-130. DOI:10.1007/s00418-011-0848-5.

Saha RK, Tuhin SHM, Jahan N, Roy A, and Roy P. 2014. Antibacterial and antioxidant activities of a food lectin isolated from the seeds of Lablab purpureus. American Journal of Ethnomedicine 1(1):8-17.

Salgia R, Harpole D, Herndon JE 2nd, Pisick E, Elias A, and Skarin AT. 2001. Role of serum tumor markers CA 125 and CEA in non-small cell lung cancer. Anticancer Research 21(2B):1241-1246.

Sauer U. 2017. Analytical protein microarrays: advancements towards clinical applications. Sensors 17:256. DOI:10.3390/s17020256.

Selvaraju S, and EI Rassi Z. 2013. Targeting human serum fucome by an integrated liquidphase multicolumn platform operating in "cascade" to facilitate comparative mass 
970

971

972

973

974

975

976

977

978

979

980

981

982

983

984

985

986

987

988

989

990

991

992

993

994

995

996

997

spectrometric analysis of disease-free and breast cancer sera. Proteomics 13:1701-1713. DOI:10.1002/pmic.201200524.

\section{Seriramalu R, Pang WW, Jayapalan JJ, Mohamed E, Abdul-Rahman PS, Bustam AZ,} Khoo AS-B, and Hashim OH. 2010. Application of champedak mannose-binding lectin in the glycoproteomic profiling of serum samples unmasks reduced expression of alpha-2 macroglobulin and complement factor B in patients with nasopharyngeal carcinoma. Electrophoresis 31(14):2388-2395. DOI:10.1002/elps.201000164.

Shah AK, Cao KA, Choi E, Chen D, Gautier B, Nancarrow D, Whiteman DC, Saunders NA, Barbour AP, Joshi V, and Hill MM. 2015. Serum glycoprotein biomarker discovery and qualification pipeline reveals novel diagnostic biomarker candidates for esophageal adenocarcinoma. Molecular \& Cellular Proteomics 14(11):3023-3039. DOI:10.1074/mcp.M115.050922.

Shan S, Tanaka H, and Shoyama Y. 2001. Enzyme-linked immunosorbent assay for glycyrrhizin using anti-glycyrrhizin monoclonal antibody and an eastern blotting technique for glucuronides of glycyrrhetic acid. Analytical Chemistry 73(24):5784-5790. DOI:10.1021/ac0106997.

Sharon N, and Lis H. 2004. History of lectins: from hemagglutinins to biological recognition molecules. Glycobiology 14:53R-62R. DOI:10.1093/glycob/cwh122.

\section{Shibuya N, Goldstein IJ, Broekaert WF, Nsimba-Lubaki M, Peeters B, and Peumans} WJ. 1987. The elderberry (Sambucus nigra L.) bark lectin recognizes the Neu5Ac(alpha 2-6)Gal/GalNAc sequence. The Journal of Biological Chemistry 262(4):1596-1601.

Silva MC, de Paula CA, Ferreira JG, Paredes-Gamero EJ, Vaz AM, Sampaio MU, Correia MT, and Oliva ML. 2014. Bauhinia forficata lectin (BfL) induces cell death and inhibits integrin-mediated adhesion on MCF7 human breast cancer cells. Biochimica et Biophysica Acta 1840:2262-2271. DOI:10.1016/j.bbagen.2014.03.009.

Silva MLS, Gomes C, and Garcia MBQ. 2017. Flow lectin affinity chromatography - A model with Sambucus nigra agglutinin. Journal of Glycobiology 6(1):1000121. 
998

999

1000

1001

1002

1003

1004

1005

1006

1007

1008

1009

1010

1011

1012

1013

1014

1015

1016

1017

1018

1019

1020

1021

1022

1023

1024

1025

Singh RS, Bhari R, Rana V, and Tiwary AK. 2011. Immunomodulatory and therapeutic potential of a mycelial lectin from Aspergillus nidulans. Applied Biochemistry and Biotechnology 165:624-638. DOI:10.1007/s12010-011-9281-4.

Sobral AP, Rego MJ, Cavalacanti CL, Carvalho LB Jr, and Beltrao EI. 2010. ConA and UEA-I lectin histochemistry of parotid gland mucoepidermoid carcinoma. Journal of Oral Science 52(1):49-54. http://doi.org/10.2334/josnusd.52.49.

Sunderic M, Sediva A, Robajac D, Miljus G, Gemeiner P, Nedic O, and Katrlik J. 2016. Lectin-based protein microarray analysis of differences in serum alpha-2-macroglobulin glycosylation between patients with colorectal cancer and persons without cancer. Biotechnology and Applied Biochemistry 63(4):457-464. DOI:10.1002/bab.1407.

Takeda Y, Shinzaki S, Okudo K, Moriwaki K, Murata K, and Miyoshi E. 2012. Fucosylated haptoglobin is a novel type of cancer biomarker linked to the prognosis after an operation in colorectal cancer. Cancer 118(12):3036-3043. DOI:10.1002/cncr.26490.

Tan Z, Yin H, Nie S, Lin Z, Zhu J, Ruffin MT, Anderson MA, Simeone DM, and Lubman DM. 2015. Large-scale identification of core-fucosylated glycopeptide sites in pancreatic cancer serum using mass spectrometry. Journal of Proteome Research 14(4):1968-1978. DOI:10.1021/acs.jproteome.5b00068.

Tanabe K, Kitagawa K, Kojima N, and Iijima S. 2016. Multifucosylated alpha-1-acid glycoprotein as a novel marker for hepatocellular carcinoma. Journal of Proteome Research 15(9):2935-2944. DOI:10.1021/acs.jproteome.5b01145.

Thomas DS, Fourkala EO, Apostolidou S, Gunu R, Ryan A, Jacobs I, Menon U, Alderton W, Gentry-Maharaj A, and Timms JF. 2015. Evaluation of serum CEA, CYFRA21-1 and CA125 for the early detection of colorectal cancer using longitudinal preclinical samples. British Journal of Cancer 113(2):268-274.

DOI:10.1038/bjc.2015.202.

Thompson IM, Pauler DK, Goodman PJ, Tangen CM, Lucia MS, Parnes HL, Minasian LM, Ford LG, Lippman SM, Crawford ED, Crowley JJ, and Coltman CA, Jr. 2004. Prevalence of prostate cancer among men with a prostate-specific antigen level $<$ or $=4.0$ 
1026

1027

1028

1029

1030

1031

1032

1033

1034

1035

1036

1037

1038

1039

1040

1041

1042

1043

1044

1045

1046

1047

1048

1049

1050

1051

1052

ng per milliliter. The New England Journal of Medicine 350(22):2239-2246. DOI:10.1056/NEJMoa031918.

Tobata-Kudo H, Kudo H, and Tada I. 2005. Strongyloides ratti: chemokinesis of glycolytic enzyme- and lectin-treated third-stage infective larvae in vitro. Parasitology International 54:147-152. DOI:10.1016/j.parint.2005.03.001.

Van Damme EJM, Lannoo N, and Peumans WJ. 2008. Plant Lectins. Advances in Botanical Research Incorporation Advances in Plant Pathology 2008, 48:107-209. DOI:10.1016/S0065-2296(08)00403-5.

Vijayan M. 2007. Peanut lectin crystallography and macromolecular structural studies in India. Journal of Biosciences 32(6):1059-1066.

Wang H, Li H, Zhang W, Wei L, Yu H, and Yang P. 2014. Multiplex profiling of glycoproteins using a novel bead-based lectin array. Proteomics 14(1):78-86. DOI:10.1002/pmic.201200544.

Wang Y, Yu G, Han Z, Yang B, Hu Y, Zhao X, Wu J, Lv Y, and Chai W. 2011. Specificities of Ricinus communis agglutinin 120 interaction with sulfated galactose. FEBS Letters 585:3927-3934. DOI:10.1016/j.febslet.2011.10.035.

Wi GR, Moon BI, Kim HJ, Lim W, Lee A, Lee JW, and Kim HJ. 2016. A lectin-based approach to detecting carcinogenesis in breast tissue. Oncology Letters 11(6):3889-3895. DOI:10.3892/ol.2016.4456.

Wu J, Xie X, Liu Y, He J, Benitez R, Buckanovich RJ, and Lubman DM. 2012. Identification and confirmation of differentially expressed fucosylated glycoproteins in the serum of ovarian cancer patients using a lectin array and LC-MS/MS. Journal of Proteome Research 11(9):4541-4552. DOI:10.1021/pr300330z.

Wu J, Xie X, Nie S, Buckanovich RJ, and Lubman DM. 2013. Altered expression of sialylated glycoproteins in ovarian cancer sera using lectin-based ELISA assay and quantitative glycoproteomics analysis. Journal of Proteome Research 12(7):3342-3352. DOI:10.1021/pr400169n. 
1053

1054

1055

1056

1057

1058

1059

1060

1061

1062

1063

1064

\section{Yamashita K, Totani K, Ohkura T, Takasaki S, Goldstein IJ, and Kobata A. 1987.} Carbohydrate binding properties of complex-type oligosaccharides on immobilized Datura stramonium lectin. The Journal of Biological Chemistry 262:1602-1607.

Yan L, Wilkins PP, Alvarez-Manilla G, Do SI, Smith DF, and Cummings RD. 1997. Immobilized Lotus tetragonolobus agglutinin binds oligosaccharides containing the $\mathrm{Le}(\mathrm{x})$ determinant. Glycoconjugate Journal 14:45-55.

\section{Zeng Z, Hincapie M, Pitteri SJ, Hanash S, Schalkwijk J, Hogan JM, Wang H, and} Hancock WS. 2011. A proteomics platform combining depletion, multi-lectin affinity chromatography (M-LAC), and isoelectric focusing to study the breast cancer proteome. Analytical Chemistry 83(12):4845-4854. DOI:10.1021/ac2002802. 